\title{
PENAFSIRAN ZAITUNAH SUBHAN DAN AMINAH WADUD TENTANG KEBEBASAN PEREMPUAN
}

\author{
Diana Khotibi \\ UIN Sunan Ampel Surabaya, Indonesia \\ Dianakhotibi32547@,gmail.com
}

\begin{abstract}
A Discourse on gender is still a controversial issue today. The emergence of various inequalities in society as well as majority injustice occurs in women. The differences in roles between men and women also characterize the culture in society. The role of women is considered limited in the domestic realm, taking care of their children and husbands, while men are not limited. Religion is accused of being one of the causes for the differences between men and women. This study uses a qualitative method with library research techniques or library research, which collects a variety of literature such as books, journals, theses, and theses that are in accordance with the topic of discussion. The results of this study include (1) interpreting the pronunciation of qawwamun in QS. al-Nisā: 34 Amina, interpreting as a leader. By setting two conditions, men have advantages over women. Second, provide for his wife with his own assets. While the meaning of the verse is to imply the functional relationship between men and women. Meanwhile, Zaitunah interprets the pronunciation of qawwāmūn as protector, or person in charge. Regarding nuฉ̆bū, Amina interpreted it as a hormonal disorder, while oliveah interpreted nuгhiz as defiance related to the relationship between humans and their gods. Regarding the progress of women in the public domain, Amina and Zaitunah agree that women should be given the same opportunity to develop themselves. Biological differences according to the two are not reasons in limiting women's movement space. (2) in interpreting the verses Amina and Zaitunah use different methods. Amina Wadud used her hermeneutic method while Zaitunah Subhan used the maudu'i (thematic) method.
\end{abstract}

Keywords: freedom, women, Amina Wadud, Zaitunah Subhan, al-Qur'an 
Penafsiran Zaitunah Subhan Dan Aminah Wadud Tentang Kebebasan Perempuan,

\section{Pendahuluan}

Pada dasarnya, sekitar lima belas abad yang lalu, Islam telah menghapus segala bentuk diskriminasi berdasarkan perbedaan jenis kelamin. Datangnya Islam ditengah masyarakat jahiliyah, menghapus segala bentuk ketidak adilan, khususnya bagi kaum perempuan yang berlangsung dalam masyarakat. Kaum perempuan dianggap sebagai makhluk yang sangat hina, mereka mengubur hidup-hidup bayi yang lahir dengan jenis kelamin perempun, hal ini mereka lakukan guna menghindari cercaan, celaan dan hinaan. ${ }^{1}$

Dalam Q.S. al-Hujurat: 13, Allah menjelaskan bahwa tidak ada perbedaan antara laki-laki dan perempuan, keduanya mempunyai kebebasan dan hak yang sama dalam hal ibadah, maupun dalam aktivitas sosial. Ayat tersebut semakin memperjalas ajaran pokok al-Qur'an yakni membebaskan manusia dari belenggu diskriminasi. Setiap laki-laki ataupun perempan mempunyai tanggung yang sama, yakni menyembah Allah. Yang membedakan hanya ketakwaan kepada Allah. ${ }^{2}$ Nasruddin Umar dalam bukunya mengatakan, bahwa terdapat lima variabel dalam menganalisis prinsip kesetaraan gender dalam al-Qur'an yaitu: ${ }^{3}$ 1) laki-laki dan perempuan sama-sama sebagai hamba, 2) laki-laki dan perempuan sebagai khalifah di bumi ${ }^{4}$, laki-laki dan perempuan menerima perjanjian primordial ${ }^{5}$, 3) Adam dan Hawa terlibat secara aktif dalam drama kosmis ${ }^{6}$, dan laki-laki maupun perempuan berpotensi meraih prestasi ${ }^{7}$

Berbanding terbalik dengan apa yang difirmankan Allah dalam alQur'an, nyatanya dalam kehidupan sosial pandangan tentang perempuan sangat jauh dengan apa yang telah digambarkan oleh al-Qur'an. Ketidak adilan gender yang mengakar dimasyarkat menimbulkan sikap diskriminatif terhadap perempuan, sehingga peran dan partisipasi perempuan dalam ranah sosial, politik, dan ekonomi relatif dibatasi dari pada laki-laki dalam ranah yang sama. Menurut Mansur Fakih, adanya ketidak adilan tersebut berdampak pada marginalisasi (pemiskinan ekonomi) terhadap perempuan sehingga, kaum perempuan akan terus menggantungkan hidupnya pada laki-

\footnotetext{
1 Al-Nahl: 58-59.

2 Q.S. Adz-Dhāriyāt: 56

3 Nasaruddin Umar, Argumen Kesetaraan Gender Perspektif al-Qur'an, (Jakarat: Paramadina, 2001), h. 248-264.

${ }^{4}$ Q.S. al-An'ām: 165

${ }^{5}$ Q.S. al-A'rāf: 172

${ }^{6}$ Q.S. al-Baqarah: 35 dan 187, al-A'raf: 20, 22, 23

${ }^{7}$ Q.S. Ali Imrān: 195, al-Nisa':124, al-Nahl: 97 dan al-Ghafir: 40
}

110 | Muṣhạaf: Jurnal Tafsir Berwawasan Keindonesiaan Volume 1. Nomor 1, Desember 2020. 
laki. Secara otomatis perempuan akan selamanya hidup diabawah kekuasaan laki-laki. ${ }^{8}$

Agama disebut-sebut sebagai salah satu sebab terjadinya ketidak adilan gender terhadap kaum perempuan. Salah satu ayat yang menjadi rujukan dalam membenarkan sikap diskriminatif terhadap perempuan adalah Q.S. al-Nisa”: 34. Lafal "al-rijäl Qawnāmün” (kepemimpinan laki-laki). Ayat ini dalam tafsir-tafsir klasik cenderung ditafsirkan secara misogini, dalam artian, memberikan norma otoritas permanen bagi semua laki-laki dalam hal memimpin perempuan yang dari situ seluruh relasi gender dibangun di segala ruang dan waktu. Pola penafsiran tersebut dapat kita temukan misalnya dalam Tafsīr al-Tabarī, Tafsīr Baiḍāwī, Tafsīr al-Qurțūbī dan Tafsīr al-Alūsī.

Al-Ṭabarī misalnya, menafsirkan lafal al-rijäl Qawwämūna 'alā al-nisä' dalam ayat tersebut menunjukkan kepemimpinan laki-laki atas perempuan. Hal ini dilihat dari anugrah yang diberikan oleh Allah terhadap laki-laki dalam segi kekuatan fisik, pendidikan, serta kewajiban dan tanggung jawab yang diberikan pada kaum laki-laki oleh Allah. Sebagaimana tercermin dalam lafal wa bimā anfaqù min amwälibim yakni, laki-laki mempunyai kewajiban membayar mahar, nafkah, dan kifäyah. Sedangkan perempuan diwajibkan untuk taat kepada suami, melaksanakan kewajiban pada suami, menjaga kehormatan dirinya dan rumah tangga, serta harta benda milik suami ketika tidak ada dirumah. ${ }^{9}$

Senada dengan al-Ṭabarī, al-Qurțubī sebagaimana dikutip oleh Fauzan Zenrif, bahwasanya laki-laki adalah pemimpin bagi kaum perempuan karena keistimewaan dalam hal menjadi hakim, berjihad, mengatur, menjaga dan melarang perempuan keluar dari rumah. Sedangkan perempuan mempunyai kewajiban taat kepada suaminya selama tidak bertentangan dengan syari'at Allah. ${ }^{10}$

Namun demikian, penafsiran tetaplah sebagai hasil dari pemikiran yang tidak terlepas dari konteks dan konstruksi sosialnya, yang dapat berubah sesuai dengan perubahan konteks tersebut. Oleh sebab itu, tidak sedikit pemikir muslim perempuan yang memperjuangkan citra peremuan dengan memberikan pandangan baru terhadap al-Qur'an dan hadis nabi. Aminah Wadud, misalnya, berpendapat bahwa dunia patriarkhi terhadap kaum perempuan disebabkan masyarakat Islam kurang peka dan gagal dalam

\footnotetext{
${ }^{8}$ Mansour Fakih, Analisis Gender dan Transformasi Sosial, (Yogyakarta: Pustaka Pelajar, 1996), h. 13-23.

9 Abu Ja'far Muhammad bin Jarir bin Yazid at-Thabari, Tafsir al-Thabari, Jilid IV, (Kairo: Bulaq $\mathrm{H}), 40$.

10 Fauzan Zenrif, Tafsir Fenomenologi Kritis: Interrelasi Fungsional antara Teks dan Realitas, (Malang: UIN-Maliki Press, 2011), h. 95.
}

111 | Muṣhạaf: Jurnal Tafsir Berwawasan Keindonesiaan Volume 1. Nomor 1, Desember 2020. 
menyadari akibat yang ditimbulkan dari perlakuan tersebut. Di sisi lain, seorang pemikir perempuan Indonesia, Zaituna Subhan, mengatakan bahwa gender merupakan pembagian peran sosial antara laki-laki dan perempuan yang mengacu pada emosi dan psikologi sesuai dengan fisik laki-laki dan perempuan. $^{11}$ Artinya gender bukanlah sesuatu yang bersifat kodrat melainkan hasil dari rekonstruksi kultur sosial.

Tulisan ini bermaksud untuk mengkaji pemikiran dua tokoh perempuan di atas, yaitu Aminah Wadud dan Zaitunah Subhan. Meski telah banyak tulisan yang mengkajinya, akan tetapi tulisan ini menempatkan gagasan dua tokoh tersebut sebagai produk pemikiran yang tidak dapat lepas dari unsur-unsur sosial-kultural yang membentuknya. Dengan demikian, tulisan ini juga akan menguji sejauh mana kemungkinan gagasan tersebut dapat diterapkan dalam konteks sosial, kebudayaan dan peradaban di Indonesia.

\section{Kebebasan Perempuan dalam Tradisi Pra Islam dan al-Qur'an}

Berbicara tentang perempuan tidak akan pernah lepas kaitannya dengan jenis klamin. Ciri-ciri yang paling dominan dari seorang perempuan dapat dilihat dari fisik dan psikisnya. Dari segi fisik misalnya, perempuan mempunyai struktur biologis serta perkembangan unsur kimia dalam tubuh yang tidak dimiliki kaum laki-laki seperti, alat reproduksi, berupa rahim, sel telur dan payudara sehingga perempuan dapat hamil, melahirkan dan menyusui. Sedangkan dilihat dari segi psikisnya, perempuan identik dengan lemah lembut, mudah rapuh dan feminim. Hal ini senada dengan pandangan Zaituna Subhan yang mengatakan bahwa perempuan identik dengan watak keibuan, tidak agresif, berhati lembut, suka menolong, emosional, ketergantungan, dan mempunyai seksualitas yang feminim. ${ }^{12}$

Selama ini, sejarah tentang perempuan dikenal sebagai sejarah yang kelam, yakni masa-masa dimana kaum perempuan diperlakukan sangat rendah bahkan nyaris disamakan dengan hewan. Selama berabad-abad perempuan dianggap sebagai makhluk yang sangat rendah. bahkan tidak jarang derajad mereka nyaris disamakan dengan hewan dan benda-benda lain yang bisa diperlakukan sesuai kehendak pemiliknya. Namun sebenarnya, tidak semua wanita mengalami penindasan sebagaimana yang telah dijelaskan pada bab sebelumnya. Banyak sekali perempuan-perempuan hebat yang mempunyai kemampuan sama bahkan melebihi kaum laki-laki pada umumnya. Misalnya pada peradaban kerajaan Mesir, nama Cleopatra,

11 Zaitunah Subhan, Al-Qur'an dan Perempuan: Menuju Kesetaraan Gender dalam Penafsiran, (Jakarta: Prenada Media Group, 2015), h. 2.

12 Ibid., 5. 
${ }^{13} \mathrm{Nefertiti}^{14}$ dan Hatshepsut ${ }^{15}$ merupakan tokoh-tokoh perempuan yang berpartisipasi langsung dalam sistem pemerintahan kerajaan Mesir yang berlangsung sekitar 3000 tahun lamanya. Mereka terkenal bukan hanya karena kecantikannya akan tetapi, juga kecerdikan dan kepandaian mereka dalam hal berpolitik. ${ }^{16}$

Ketika berbicara tokoh perempuan, kita juga mengenal para perempuan hebat yang tercantum dalam QS. al-Qașaș: 09. Pada ayat tersebut, al-Qur'an menjelaskan sosok Aisyah, Istri Fir'un, sebagai wanita pejuang. Aisyah memiliki ketangguhan, kemandirian dan kepribadian yang kuat dalam menentang kedzoliman suaminya. Di dalam al-Qur'an nama Aisyah tidak disebutkan secara gamblang, namun sebagaimana dalam tafsir Kementrian Agama bahwasanya, para ulama tafsir menyatakan nama dari istri fir'aun adalah 'Aisyah. ${ }^{17}$ Al-Qur'an juga tida menjelaskan bagaimana paras dari istri fir'aun tersebut, al-Qur'an hanya menjelaskan karakter dan keimanan yang begitu kuat dari 'Aisyah.

Perempuan lain yang disebut dalam al-Qur'an adalah Ratu Balqis. Ratu Bilqis adalah seorang pemimpin kerajaan negeri Saba' (saat ini dikenal dengan negara Yaman) yang sangat kaya raya. ${ }^{18} \mathrm{Al}$-Qur'an mengisyaratkan pada QS. Al-Naml: 23. Ratu Balqis dikenal sebagai ratu yang arif dan bijaksana, dengan sistem pemerintahan yang demokratis. Ia sangat disegani oleh para pengikutnya. Dibawah kepemimpinannya negeri Saba' menjadi negeri yang makmur, sampai-sampai Allah menyebut negeri tersebut sebagai "Baldatun tayyibun wa robbun ghafür" yaitu negeri yang aman, sentosa, lagi sejahtera dan mendapat ampunan dari Allah. ${ }^{19}$ Ratu Balqis adalah sosok pemimpin yang sangat memperhatikan keselamatan rakyatnya Segala

${ }^{13}$ Cleo patra (VII/ tahun 69-30 SM) disebut sebagai fir'aun perempuan yang terkenal karena kisah asmaranya dengan penguasa kerajaan Romawi yakni Julius Caesar, serta kecerdikannya dalam hal berpolitik.

${ }^{14}$ Nefertiti adalah istri dari fir'aun Akhenaten (Amenhotep IV), ia naik tahta sekitar 1353 SM. Ia sempat memimpin kerajaan Mesir meskipun hanya sebentar. Patung Nefertiti sampai sekarang menjadi koleksi masterpice museun di Jerman, kecantikannya telah banyak mngispirasi kaum perempuan.

15 Hatshepsut merupakan permaisuri dari raja Tuthmosis II. Ia juga sempat memegang kekuasaan pemerintah Mesir setelah suaminya meniggal. Kekuasaanya berlangsung sekitar tahu 1479 SM bhkan ia sempat menyebut dirinya sebagai Dewa Amun.

16 Ali Akbar, Arkeologi Al-Qur'an: Penggalian Pengetabuan Keagamaan (Jakarta: Lembaga Kajian dan Peminatan Sejarah, 2020), 61.

${ }^{17}$ Kementrian Agama Republik Indonesia, Al-Qur'an dan Tafsimya (Jakarta: Lentera Abadi, 2010), 213.

${ }^{18}$ Ibnu Kathīr, Tafsìr al-Qur'ān al-Ažim, juz 19, terj. Bahrul Abu Bakar (Bandung: Sinar Baru Algensindo, 2004), 281.

${ }_{19}$ QS. Al-Saba' : 15.

113 | Muṣhạa: Jurnal Tafsir Berwawasan Keindonesiaan Volume 1. Nomor 1, Desember 2020. 
keputusa yang ia ambil selalu berdasarkan sebab akibat yang ditimbulkan terhadap rakyatnya. Oleh sebab itu, ia lebih menyukai cara-cara halus dalam menyelesaikan berbagai macam persoalan.

Dikisahkan dalam al-Qur'an bahwa Ratu Balqis menerima surat dari Nabi Sulaiman, yang isinya mengajak Ratu Bilqis agar menyembah Allah, berserah diri kepada Allah dan tidak sombong. Walaupun isi surat tersebut bertentangan dengan keimanannya ${ }^{20}$ akan tetapi Ratu Balqis tetap menganggap surat kiriman Nabi Sulaiman sebagai surat yang mulia atau agung, Tabatabā'ì mengatakan dalam tafsirnya bahwasanya, sikap Ratu Balqis tersebut lantaran yang mengirim surta tersebut adalah Nabi Sulaiman yang telah ia kenal kekuasaannya, serta adanya penyebutan nama "Allah" dalam surat tersebut kendati pada saat itu Ratu Balqis belum beriman. ${ }^{21}$ Berbeda dengan Tabațabā̄ō, Sayyid Qutb mengatakan bahwa sikap Ratu Balqis dikarenakan isi dari pada surat tersebut bertujuan menghindari adanya perselisihan dan peperangan, walaupun tidak ditulis secara terang-terangan. ${ }^{22}$

Selain mempunyai sikap yang bijaksana sebagai pemegang kekuasaan tertinggi, Ratu Balqis juga pandai dalam hal berpolitik. Ia lebih mengutamakan cara-cara halus dalam mencari solusi dalam setiap permasalahan, dan tidak menyukai kekerasan. Hal ini terbukti dengan ditolaknya berbagai usulan dari pembesar kerajaan untuk memerangi Nabi Sulaiman, yang kemudian diganti dengan mengirimkan berbagai macam hadiah kepada Nabi Sulaiman. ${ }^{23}$

Setelah Islam datang, ada sejumlah nama perempuan yang dikenal sebagai perempuan tangguh dan berkepribadian mandiri. Sebut saja misalnya Khadijah bint Khuwailid, istri nabi. Sosok khadijah sudah begitu familiar di kalangan umat Islam. Umat Islam biasa memanggilnya dengan sebutan Siti Khadijah atau Khadijah al-Kubro. Ia berasal dari keturunan pembesarpembesar suku Quraisy, dari pasangan Khuailidi bin Asad bin Abd. Uzza bin Qushai dan Fatimah binti Za'idah. Rasulullah menikahi Khadijah pada usia 40 tahun sedangkan Rasulullah sendiri masih berumur 25 tahun. $^{24}$

Khadijah adalah sosok wanita karir yang sukses dalam menggeluti dunia bisnis. Selain itu Khadijah juga merupakan sosok perempuan

${ }^{20}$ Sebelum masuk Islam Ratu Bilqis beserta rakyatnya meyakini matahari sebagai Tuhan mereka. Lihat QS. Al-Naml [27]: 24.

${ }^{21}$ Sayyid Muhammad Husain Thabatab’i, Tafsir al-Mizan, Juz 15, 0, 368.

22 Sayyid Quṭ, Tafsì fì Ziläli al-Qur'ān, juz 8, Terj. As'ad Yasin, dkk, (Jakarta: Gema Insani Press, 2000), 398.

23 Zaitunah Subhan, Al-Qur'an dan Perempua: Menuju Kesetaraan Gender dalam Penafsiran, (Jakarta: Prenada Media Group, 2018), 398.

${ }^{24}$ Ibrahim Muhammad Hasan al-Jamal, Khadijah Teladan Agung Wanita Mukminah, Cet. 1, Trj. Khalid Abdullah dkk. (Jawa Tengah:Insan Kamil, 2014), 17. 
pendobrak tardisi patriarkhi terhadap kaum perempuan pada masa Arab Jahiliyah. Sebut saja ketika ia ingin meminang Rasulullah, ia mendapat tentangan dari tradisi Arab pada waktu itu bahwa, seorang perempuan pantang terlebih dahulu meminang seorang laki-laki. Namun Khadijah tetap melanjutkan niatnya untuk meminang Rasulullah tanpa menghiraukan segala kritik dan cercaan dari keluarga dan masyarakat. ${ }^{25}$

Khadijah juga merupakan seorang istri yang selalu setia mendampingi Rasulullah dalam muyampaikan ajaran Islam. Ia selalu ada untuk Rasulullah kala suka maupun duka. Misalnya ketika Rasulullah berangkat ke Gua Hira', Khadijah selalu mempersiapkan segala perbekalan yang dibutuhkan Rasulullah selama berada dalam Gua tersebut. Sesekali ia datang menyambangi Rasulullah tatkala beliau lama di Gua Hira' guna memastikan keselamatan daripada suaminya (Nabi Muhammad). Sebagai seorang istri, Khadijah menjadi tempat Nabi bersandar menyampaikan keluh kesahnya, sebagaimana ketika untuk pertama kalinya Nabi Muhammad menerima wahyu dari Allah. ${ }^{26}$

Khadijah bagi umat Islam bukan hanya dikenal sebagai istri dari Nabi Muhammad akan tetapi, ia adalah sosok figur perempuan yang berpartisipasi langsung dalam mensukseskan dakwah Nabi. Predikat "ummul mu'minin" yang disandangnya merupakan sebuah penghormatan yang luar biasa terhadap kaum perempuan. Ia juga dikenal dengan kedermawanannya dalam menyumbangkan seluruh hartanya demi mendukung dakwah Nabi dalam menyebarkan agama Islam. Selain itu, Khadijah juga mempunyai gelar "Ath Thabirab" (wanita suci). Gelar ini disematkan kepadanya lantaran Khadijah dapat menjaga kesucian dirinya selama menjadi janda dari suami sebelumnya, walaupun ia hidup dalam kemewahan sampai ia menjadi istri dari baginda $\mathrm{Nabi}^{27}$

Selain khadijah, perempuan yang kiprahnya bagi Islam tidak diragukan lagi adalah Āishah bint Abī Bakr, Istri nabi. 'Aisyah terkenal sebagai wanita yang sangat cerdas dan sangat senang menimba ilmu. Kesempatan menjadi istri Rasulullah selain melayani dan mendampingi Rasulullah, ia juga sering menimba ilmu langsung dari sang suami (Rasulullah). Maka tidak heran apabila Siti 'Aisyah tercatat sebagai periwayat hadist terbanyak dari pada istri-istri Rasulullah yang alin serta sahabatsahabat beliau. Kecerdasannya, membuat Siti 'Aisyah menguasai berbagai bidang ilmu pengetahuan seperti al-Qur'an, Tafsir, hadist, ilmu fikih, syair-

\footnotetext{
${ }^{25}$ Ibid., 436

${ }^{26}$ Ibid., 438.

${ }^{27}$ Syarifatil Munawwarah, Siti Khadijad Ummul Mukminin: Biografi dan Peran dalam Mendampingi Rasulullah (Skripsi: UIN Alauddin Makassar, 2018), 16.
}

115 | Muṣhaf: Jurnal Tafsir Berwawasan Keindonesiaan Volume 1. Nomor 1, Desember 2020. 
syair Arab serta ilmu kesehatan. Para sahabat (laki-laki atau perempuan) seringkali menjadikan 'Aisyah sebagai sumber refrensi serta tempat bertanya mengenai sesuatu yang belum diketahui setelah Rasulullah Wafat. Hal ini juga diakui oleh Rasulullah dalam sabdanya:" Ambil sebagian agama (ajaran dan pengetahuan) agama pada humaira." 28

Banyak sekali para cendekiawan dari berbagai penjuru dunia datang kepada Siti Aisyah semata-mata ingin menimba ilmu darinya seperti, Irak, Syam, dan dari negara Mesir. Semangatnya dalam memberikan ilmu pengetahun kepada orang lain tak kenal kapanpun dan dimanapun ia berada. Bahkan saat melakasanakan ibadah haji sekalipun. Siti 'Aisyah selalu melayani berbagai macam pertanyaan baik menyangkut ajaran Islam maupun persoalan pribadi. Jawaban yang ia kemukakan sesuai dengan al-Qur'an dan hadist Nabi, sehingga orang-orang yang mendengarkanpun merasa puas dengan setiap jawaban dari Siti 'Aisyah. ${ }^{29}$

Selain cerdas, 'Aisyah adalah sosok perempuan pemberani. Ia turut berpartisipasi langsung dalam peperangan yg diikuti oleh Rsulullah. Ia pernah ikut serta dalam perang uhud sebagai penyedia air minum bagi pasukan umat Islam, perang ahzab serta yang paling fenomenal adalah partisipasinya dalam perang jamal. Dalam perang tersebut ia bahkan harus melawan Ali bin Abi Thalib yang pada saat itu ditetapkan sebagai khalifah sekaligus sepupu dan menantu dari Rasulullah. ${ }^{30}$

Sosok Sakinah bint al-Hussein juga merupakan nama yang selalu dikenang umat Islam sepanjang masa. Kisahnya, setelah berakhirnya masa pemerintahan khalifah yang pertama, kemudian digantikan dengan masa kekuasaan pemerintah dinasti Umayyah. Saat itu pula kekuasaan diambil alih oleh kaum perempuan bangsawan Arab. Mereka menuntut hak-hak mereka seperti mengahapus larangan memakai cadar bagi kaum perempuan serta menolak adanya hak suami dalam berpoligami. Salah satu tokoh yang paling dominan dalam menyauarakan hak-haknya adalah, Sakinah binti Hussein. Ia termasuk perempuan dari kalangan bangsawan Arab yang mempunyai paras yang sangat cantik. Sakinah binti Hussein adalah cucu dari Rasulullah serta istri dari khalifah Ustman bin Affan. Sakinah dikenal sebagai perempuan yang mempunyai ilmu pengetahuan tinggi dan pandai dalam hal menulis. ${ }^{31}$

Realitas historis diatas menunjukkan bahwa tidak seluruhnya sejarah tentang perempuan merupakan sejarah yang kelam. Kaum perempuan juga

${ }^{28}$ Ibid., 441

${ }^{29}$ Ibid., 273

${ }^{30}$ Hadiyah Salim, Wanita Islam: Kepribadian dan Perjuangannya (Bandung: PT Remaja Rosda Karya, 1991), 19.

31 Asghar Ali Engineer, Matinya Perempuan: Transformasi al-Qur'an, Perempuan dan Masyarakat Modern, terj. Ahmad Affandi dan Mu Ihsan, (Yogyakarta: IRCiSoD, 2003), 25.

116 | Muṣhaf: Jurnal Tafsir Berwawasan Keindonesiaan Volume 1. Nomor 1, Desember 2020. 
mempunyai hak yang sama dalam memperoleh kebebasan yang setara dengan kaum laki-laki. Kisah-kisah tersebut juga mematahkan keyakinan orang-orang Yahudi dan Nasrani yang mengatakan bahwa perempuan adalah sumber kerusakan dan mala petaka, sebagaimana yang telah penulis singgung diatas.

Pada beberapa ayat dalam al-Qur'an, dijelaskan pola hubungan antara laki-laki dan perempuan. Pertama, al-Qur'an menegaskan bahwa seluruh manusia memiliki kesempatan yang sama untuk mencapai kemuliaan di sisi Allah. Keterangan ini terdapat pada QS. Ali Imran: 195. Ayat ini menjelaskan tidak adanya perbedaan baik laki-laki ataupun perempuan, bagi siapa saja yang mau berdo'a kepada Allah niscaya Allah akan mengabulkan. Tidak ada yang sia-sia bagi Allah, segala jerih payah dan amal perbuatan baik itu lakilaki atau perempuan akan dibalas dengan ganjaran sesuai dengan apa yang manusia lakukan. Selain ayat di atas, ada sejumlah keterangan dalam alQur'an yang menunjukkan kesamaan antara laki-laki dan perempuan, misalnya QS. al-Naḥl: 97, QS. al-Nisā' : 124, QS. al-Māidah: 38, QS. alMu'min: 40, QS. al-Fatḥ: 5-6, QS.al-Ḥadīd: 12, QS. al-Nūḥ: 28, QS. al-Nūr: 2,12 dan 26, QS. al-Aḥzāb: 35 dan 37, serta QS. al-Tawbah: 71-72.

Kedua, laki-laki dan perempuan diberi kebebasan untuk menuntut ilmu. Manusia adalah makhluk Tuhan yang paling istimewa, mereka diberikan kemampuan akal yang sempurna diantara makhluk Allah yang lain. Dengan akal yang sempurna manusia mempunyai pengetahuan, inisiatif, keterampilan dan dapat membedakan mana yang baik dan mana buruk. Itulah mengapa Allah memerintahkan malaikat untuk bersujud kepada Nabi Adam, sebagaimana firman Allah dalam QS. Al-Baqarah :31-34. Selain menggunakan akalnya, manusia juga diajurkan untuk selalu mengasah otaknya dengan pendidikan dan berbagai macam ilmu. Dan Allah akan memberikan imbalan berupa derajat dan tingkatan yang lebih tinggi sebagaimana yang tertera dalam QS. Al-Mujādalah: 11.

Sebenarnya, pentingnya menunutut ilmu telah dipraktikkan sejak zaman Rasullullah, yang mana Bukhari sebagaiamana dikutip oleh Zaituna Subhan dalam bukunya bahwasanya salah seorang sahabat perempuan datang menemui Rasulullah kemudian berkata:'Kaum laki-laki banyak yang mendapat ilmu darimu, sedangkan kami perempuan juga ingin mempunyai waktu untuk mempelajari apa yang telah disampaikan oleh Allah padamu." Kemudian Rasulullah bersabda:" Berkumpullah pada hari dan tempat tertentu" kemudian kaum perempuan berkumpul dan belajar bersama dengan Rasulullah.

Melihat betapa pentingnya pendidikan bagi laki-laki ataupun perempuan, sehingga dalam QS. Al-Tawbah: 122, Allah memerintahkan 
Penafsiran Zaitunah Subhan Dan Aminah Wadud Tentang Kebebasan Perempuan,

kepada manusia agar supaya meninggalkan negerinya demi mendalami berbagai macam ilmu pengetahuan. Ayat tersebut senada dengan hadist Nabi yang populer dikalangan masyarakat:" Tuntutlab ilmu sampai ke negari Cina." Dalam hal pentingnya menuntut ilmu. Walaupun Ali Mustafa Ya'qub dalam bukunya menggolaongkan hadist tersebut sebagai hadist maudü', karena salah satu sanadnya dianggap lemah dan tidak memiliki kredibilitas dalam meriwayatkan hadist. Bahkan ia mengatakan bahwa masyarakat tidak boleh menganggap kalimat tersebut sebagai hadist namun, hanya sebagai kata mutiara. ${ }^{32}$

Ketiga, laki-laki dan perempuan diberi kebebasan dalam menentukan pasangan hidup. Tujuan utama manusia dalam berpasangan, sebagaimana dalam QS. Al-Rūm: 21, agar supaya saling melengkapi satu sama lain serta memperoleh ketentraman dan ketenangan dalam menjalani kehidupan. Agama Islam memberikan kebebasan bagi laki-laki ataupun perempuan dalam menentukan pilihannya sesuai dengan apa yang mereka inginkan. Kebebasan tersebut tertuang dalam QS. al-Nuū: 32. Namun dalam realitas sosial saat ini sebagian dari masyarakat masih memberikan kewenangan sepenuhnya untuk memilih pasangan kepada orang tua yang dalam kajian fiqh biasa disebut ijbar (ijbar adalah kewenagan bagi wali atau orang tua dalam memilih pasangan hidup untuk anaknya). ${ }^{33}$

Dalam Islam kebebasan untuk memilih bukan hanya diperuntukan bagi kaum laki-laki namun juga terhadap kaum perempuan, untuk terciptanya tujuan pernikahan yankni sakinah, mawaddah dan warahmah. Orang tua hanya diberikan kewenagan dalam hal menasehati dan mengarahkan, bukan memaksa seorang anak agar mengikuti kehendaknya. Hal ini sesuai dengan hadist Nabi bahwasanya Khuntsa bint Khudzam pernah datang kepada Rasulullah dan menceritakan bahwa ia telah dijodohkan oleh orang tuanya dengan laki-laki yang tida disukai olehnya. Kemudian Rasulullah bersabda:"Janganlah kamu (wahai bapak) menikabkan anak perempuanmu sementara dia tidak menyuakinya." 34 Senada dengan hadist tersebut bahwasanya Rasulullah bersabda: "Janda lebib berhak atas dirinya dari pada walinya, dan perawan harus dimintai izin oleb ayahnya mengenai dirinya, dan izinnya adalah diamnya." 35

Keempat, kebebasan dalam mengaktualisasikan diri. Sejatinya di dalam al-Qur'an tidak ada satu ayat pun yang mengatakan atau bahkan

\footnotetext{
32 Ali Mustafa Ya'qub, Hadist-Hadist Bermasalah (Jakarta: Pustaka Firdaus, 2003), 3.

${ }^{33}$ Ibid., 136

${ }^{34}$ Imām al-Nasā̄ì, Sunan Nasā’̀, terj. Bey Arifin dan Yunus Ali Mukhdo (Semarang: CV Asy Syifa, 1992), Cet. 1, 649.

${ }^{3}$ Ibd., 59
}

118 | Muṣhạa: Jurnal Tafsir Berwawasan Keindonesiaan Volume 1. Nomor 1, Desember 2020. 
mengisyaratkan bahwa, derajat laki-laki satu tingkat lebih tinggi dari pada kaum perempuan. Namun, kadangkala struktur budaya lebih mendominasi dari teks al-Qur'an itu sendiri. Dalam QS. Al-Tawbah: 71, perempuan maupun laki-laki sama-sama mengemban kewajiban dari Allah. Allah tidak membedakan baik laki-laki ataupun perempuan. Bahkan Allah memerintahkan agar supaya keduanya saling bekerja sama dalam menegakkan "amar ma'ruf nahi mungkar." Hamka dalam tafsirnya mengatakan bahwa, ayat tersebut mengandung maksud ukhuwah bagi sesama umat Islam. Laki-laki ataupun perempuan seyogyanya harus saling tolong menolong, serta bimbing membimbing dalam menegakkan kebenaran. Oleh karena setiap orang mukmin bersatu dalam satu i'tiqad yakni kepercayaan kepada Allah. ${ }^{36}$

Kewajiban tersebut bersifat universal baik laki-laki ataupun perempuan. Perempuan sebagai patner laki-laki bukan hanya dalam konteks keluarga akan tetapi Islam memberikan kebebasan seluas-luasnya bagi kaum perempuan dalam mengaktualisasikan kemampuannya semata-mata untuk kepentingan umat. Sehingga posisi perempuan bukan hanya sebagai objek akan tetapi juga sebagai subjek.

Dalam tafsir al-Maraghi, menjelaskan bahwa ayat tersebut labih kepada arti mengasibi dalam artian saling tolong menolong, bahu membahu dalam kesusahan, serta saling menguatkan sebagaimana yang telah dicontohkan oleh Nabi dan para sahabat. Hal ini karena adanya lafad ba'dubum awliyä'u ba'din yang mengandung arti orang-orang mukmin adalah satu tubuh. Apabila satu tubuh merasakan sakit maka bagian tubuh yang lain akan merasakan pula. Misalnya pada zaman Rasulullah, para istri turut berperan aktif dalam peperangan. Mereka menyediakan segala kebutuhan dimedan perang seperti, air minum, makanan, bahkan kadangakala terjun langsung dalam peperangan serta membangkitkan semangat bagi orangoarang yang kalah. ${ }^{37}$

\section{Sketsa Kehidupan Amina Wadud Dan Zaitunah Subhan Serta Kontribusi Pemikirannya}

\section{Biografi Aminah Wadud: Latar Belakang Akademik}

Amina Wadud Muhsin atau biasa dikenal dengan sebutan Amina Wadud merupakan salah satu intelektual muslim yang aktif menyuarakan

\footnotetext{
36 Abdul Karim Amirullah, Tafsìr al-Az̧har, Jilid 4 (Singapur: Pustaka Nasional PTE LTD, 1989), 729.

37 Ahmad Mustafa Al-Maraghi, Terjemah Tafsir al-Maragbi, Jilid 14, (Semarang: CV. Toha Putra Semarang, 1992), Cet. 2, 271.
}

119 | Muṣhaf: Jurnal Tafsir Berwawasan Keindonesiaan Volume 1. Nomor 1, Desember 2020. 
pendapatnya terhadap isu gender. Ia berasal dari Amerika Serikat tepatnya di desa Baethesda Maryland. Amina, lahir pada tanggal 25 September tahun 1952 M dengan nama Mary Teasley. Ia lahir ditengah-tengah keluarga yang menganut keyakinan kristen ortodok ${ }^{38}$ kemudian pada tahun 1972 ia menjadi muallaf dan berganti nama menjadi Amina Wadud Muhsin pada tahun 1974. ${ }^{39}$ Hari tersebut merupakan hari bersejarah dalam kehidupan Amina Wadud, sehingga ia memberi nama hari tersebut dengan "Thanks giving day." Syahiron Syamsuddin dalam bukunya mengungkapkan bahwa adanya ketertarikan Amina Wadud terhadap Islam bermula dari ketakjubannya akan konsep keadilan pada ajaran Islam. ${ }^{40}$

Amina Wadud memulai pendidikan dasar hingga tingkat menegahnya di Negara Malaysia. Kemudian ia melanjutkan pendidikan strata satu (S1) pada tahun 1970 di Universitas of Pennsylvania, lalu menempuh program master (S2) dan doktoralnya di Universitas of Michigan Amerika Serikat sekitar tahun 1982 dan selesai pada tahun 1988 M. Riwayat pendidikannya tidak sebatas pendidikan formal saja namun, ia juga pernah mengikuti Advance Arabic (kursus bahasa Arab) serta belajar studi al-Qur'an dan tafsir di Cairo University sedangkan in Philosophy (ilmu filsafat) di Universitas AlAzhar. ${ }^{41}$ Karena semangatnya untuk terus mempelajari berbagai literatur keIslaman maka, ia pernah dinobatkan sebagai Guru Besar Studi keIslaman jurusan Filsafat dan Agama di Universitas Virginia Commonwealth.

Amina Wadud adalah salah satu feminisme muslim yang sangat produktif dalam menanggapi isu-isu gender. Ia hadir ditengah-tengah merebaknya perlakuan patriarkhi terhadap kaum perempuan. Amina menuangkan segala kegelisahan intelektualnya mengenai ketidakadilan gender dalam bentuk karya tulis seperti, buku dan artikel yang telah tersebar dalam berbagai jurnal. Salah satu karyanya yang paling fenomenal adalah buku yang berjudul Qur'an and Women dan Inside the Gender Jihad, Reform in Islam. $^{42}$ Buku ini merupakan hasil penelitian Amina Wadud tentang perempuan dalam al-Qur'an. Penelitian ini ia lakukan sembari melanjutkan studinya di Universitas of Michigan. Kurzman mengatakan, munculnya buku

\footnotetext{
38 Kristen ortodoks dalam segi bahasa berakar dari kata "orthos" yaitu lurus dan kata "doxa" yang berarti sebuah ajaran. Jadi kristen ortodok mengandung arti ajaran yang lurus. Nama ortodoks digunakan karena para penganutnya memnginginkan hidup secara lurus sesuai dengan sejarah pertama kali terbentuknya agama tersebut.... Lihat Lutfiani Lestari, Studi Tentang Kristen Ortodoks Yunani di Surabaya, (Skripsi: UIN Sunan Ampel Surabaya, 2018), 3.

39 Irsyadunnas, Tafsir Ayat-Ayat Gender Ala Amina Wadud Perspektif Hermeneutika Gadamer, Jurnal Musawa, Vol. 14, No. 2, 2015, 8.

${ }^{40}$ Syahiron Syamsuddin, Hermeneutika Al-Qur'an dan Hadist (Yogyakarta: eLSAQ, 2008), 4.

${ }^{41}$ http://dedikayunk.wordpress.com/2014/11/19/biografi-dan-pemikiran-amina-wadud/

${ }^{42}$ M. Yusron, Studi Kitab Tafsir Kontemporer, (Yoyakarta:TH-Press, 2006), 81.
}

120 | Muṣhaf: Jurnal Tafsir Berwawasan Keindonesiaan Volume 1. Nomor 1, Desember 2020. 
ini erat kaitannya dengan pengalaman Amina Wadud sendiri. Amina melihat adanya perlakuan bias patriarkhi terhadap perempuan sehingga, kaum perempuan kurang mendapat keadilan yang sama dengan kaum laki-laki. ${ }^{43}$

Dalam buku ini, ia menawarkan interpretasi ulang terhadap ayat-ayat al-Qur'an yang bernuansa misogini dengan cara: Pertama, meninjau ulang kata-kata dalam al-Quran. Kedua, menganalisis prior teks (persepsi, keadaan, dan latar belakang teks). ${ }^{44}$ Buku ini menyumbangkan dimensi keilmuan yang banyak diapresiasi oleh para intelektual muslim dan akademisi. Begitu fenomenalnya buku ini hingga diterbitkan berulang kali dengan versi bahasa yang berbeda-beda diantaranya, bahasa Turki, Arab, inggris dan Indonesia. Bahkan pernah dinobatkan sebagai salah satu daftar buku best seller alQalam (koran muslim). ${ }^{45}$

Selain buku di atas, Aminah Wadud juga menulis tentang Inside the Gender Jibad: Reform in Islam. Latar belakang munculnya buku Amina yang kedua ini hampir sama dengan buku Qur'an and Women, yaitu berangkat dari fenomena sosial tentang gender yang ada disekitarnya. Perlakuan tidak adil yang didomonasi oleh kaum perempuan membuatnya gelisah. Menurutnya perlakuan tidak adil tersebut mengakibatkan kaum perempuan semakin hari semakin terpuruk dan termarginalkan. Bahkan agama dijadikan sebagai sumber pembenaran dari segala ketidak adilan tersebut. Sebagai seorang perempuan, Amina tidak bisa diam begitu saja melihat ketimpanganketimpangan yang terjadi disekitarnya. Oleh sebab itu, ia merasa perlu berjuang (jihad) dalam menegakkan hak-hak perempuan. Menurutnya, perlu adanya pentafsiran ulang ayat-ayat yang ditafsirkan oleh para mufassir klasik, sehingga sesuai degan era sekarang. ${ }^{46}$ Amina wadud, sebagaimana dikutip oleh Syahiron Syamsuddi dalam buku Inside The Gender mengatakan kedua karyanya tersebut ditulis setelah ia menjadi janda selama 30 tahun dengan empat orang anak. ${ }^{47}$

\section{Metodologi Tafsir Amina Wadud}

Model penafsiran hermeneutika diakui oleh Amina Wadud terinspirasi dari metodologi yang pernah ditawarkan oleh Fazlur Rahman. ${ }^{48}$ Rahman

\footnotetext{
${ }^{43}$ Charles Khurzman, Wacana Islam Liberal: Pemikiran Islam Kontemporer Tentang Isu-Isu Global, (Jakarta: Paramadina, 2001), 127.

${ }^{44}$ Amina Wadud Muhsin, Wanita dalam Al-Qur'an, terj. Yaziar Radianti, (Bandung: Pustaka,1992), 1.

45 Ibid., 72.

${ }^{46}$ Erlan Muliadi, Telaah atas Pemikiran Amina Wadud Mubsin dalam "Inside The Gender Jihad: Women's refprm in Islam"(Jurnal: al-Qawwam, 2017), Vol. 11, No. 2, 12.sssss

${ }^{47}$ Ibid., 180.

${ }^{48}$ Qur'an and Women, 5
}

121 | Muṣhaf: Jurnal Tafsir Berwawasan Keindonesiaan Volume 1. Nomor 1, Desember 2020. 
mengatakan bahwa, setiap ayat al-Qur'an yang diturunkan disertai dengan spesifikasi waktu yang tercatat dalam sejarah dengan keadadan yang general dan particular. Akan tetapi, pesan dari pada ayat al-Qur'an tidak secara otomatis dibatasai oleh keadaan yang bersifat historis tersebut. Sehingga para pembaca harus mampu memahami implikasi (yang tersirat) dari pernyataan al-Qur'an sewaktu diwahyukan guna menentukan makna utamanya. Rahman menyebut metodologinya dengan nama double movement. ${ }^{49}$

Berdasarkan argumen tersebut, Amina yakin bahwa cara satu-satunya untuk memelihara relevansi dari ayat al-Qur'an adalah dengan menafsirkan ulang ayat al-Qur'an itu sendiri. Hal ini senada dengan perkataan 'Alī bin Abī Tāālib:”Al-Qur'an ditulis pada dua garis lurus dan berada diantara dua cover, dia tidak berbicara dengan sendirinya, ia membutuhkan penafsir dan penafsiranya adalah manusia." ${ }^{50}$ Pendapat serupa juga disampaikan oleh Muhammad Shaḥrūr bahwasanya terbukanya penafsiran terhadap al-Qur'an merupakan sebuah konsekwensi logis yang menunjukkan al-Qur'an săliḥ li kulli zamān wa makān. ${ }^{51}$

Namun demikian, perlu dicatat bahwa terdapat problem bahasa dan prior text (latar belakang, dan keadaan individu seorang mufassir) dalam penafsiran al-Qur'an. Keterpengaruhan hasil penafsiran dengan prior text berdampak pada hilangnya objektifitas dari makna al-Qur'an itu sendiri. Oleh sebab itu, untuk menghindari relativisme dalam sebuah peafsiran, seorang mufassir harus bisa menangkap prinsip fundamental yang tak dapat berubah dalam teks al-Qur'an itu sendiri kemudian sang mufassir harus melakukan sebuah refleksi penafsiran yang relevan dengan zamannya. ${ }^{52}$

\section{Biografi Zaitunah Subhan; Latar Belakang Akademik}

Zaitunah Subhan lahir di Gresik Jawa Timur, tepatnya pada tanggal 10 Oktober 1950 dari keluarga santri. Ia merupakan putri ketiga dari pasangan H. Subhan Fadlan dan Hj. Salamah Marzuki. Zaituna merupakan seorang istri dari Prof. Dr. Artani Hasbi, dan dikaruniai 3 putra dan 6 cucu. ${ }^{53}$ Ia pernah menimba ilmu di dua pesantren yaitu Pondok Pesantren Maskumambang Gresik selama tiga tahun dari Ibtidaiyah sampai Tsanwiyah kemudian melajutnya pendidkan Aliyah di Pndok Pesantren Ihyaul Ulum

${ }^{49}$ Fazlur Rahman, Islam dan Modernitas: Tantangan Transformasi Intelektual, (Bandung: Puataka, 1985), 4.

50 Mutrofin, Kesetraan Gender dalam Pandangan Amina Wadud dan Riffat Hasan, Jurnal: Tasawwuf dan Pemikiran Islam, 2013), Vol.3, no. 1, 10.

${ }^{51}$ Muhammad Shahrūr, Metodologi Fikih Islam Kontemporer, Terj. Syahiron Syamsuddin dan Burhanuddin, (Yogyakarta: eLSAQ Press, 2004), 24.

${ }^{52}$ Charlez Kurzmen, 130

53 Al-Qur'an dan Perempuan, 471.

122 | Muṣhaf: Jurnal Tafsir Berwawasan Keindonesiaan Volume 1. Nomor 1, Desember 2020. 
Penafsiran Zaitunah Subhan Dan Aminah Wadud Tentang Kebebasan Perempuan,

selama dua tahun lamanya. Kemudian pada tahun 1967 Zaitunah melanjutkan strata satunya di Fakultas Ushuluddin IAIN Sunan Ampel Surabaya angkatan pertama. Pada tahun 1970 ia lulus dengan gelar Sarjana Muda (BA) Baru pada tahun 1974 ia menyempurnakan gelarnya menjadi (Dra) jurusan perbandingan Agama. Tidak berhenti sampai disitu, Zaitunah kemudian mendapat beasiswa melanjutkan studi Magisternya di Univrsitas al-Azhar Dirasat al-'Ulya Kairo Mesir sampai tahun $1978 .^{54}$

Sekembalinya dari Mesir tahun 1978, ia aktif menyandang almamater sebagai Dosen Tetap pada Fakultas Ushuluddin IAIN Sunan Ampel Surabaya sampai sekarang dengan pangkat Pembina Utama Muda/Lektor Kepala (IV/c). Pada tahun 1996 Zaitunah melanjutkan studi S3 di Pascasarjana UIN Syarif Hidayatullah Jakarta, melalui program Doktor Bebas Terkendali angkatan pertama samap tahun $1998 .{ }^{55}$ Selain aktif sebagai Dosen sekaligus Guru Besar, Zaitunah juga aktif dalam berbagai kegiatan organisasi diantaranya pengalaman organisasi di IAIN Sunan Ampel Surabaya yaitu ketua KPSW (Kelompok Pengembangan Studi Wanita) tahun 1991-1995, dan ketua PSW (Pusat Studi Wanita) tahun 1995-1999. Sedagkan diluar kampus yaitu sebagai Ketua Devisi Hubungan antar Organisasi Wanita (ICMI Orwil Jawa Timur) tahun 1995-2000 serta menjadi anggota Pokja P2W Pemda Jawa Timur. ${ }^{56}$

Pada tahun 2000 Zaitunah Subhan mendapat amanat tugas negara untuk masuk dalam jajaran birokrasi di Kementrian Pemberdayaan Perempuan Republik Indonesia sebagai staf ahli bidang ilmu agama. Tahun 2001 mengikuti SPIMNAS (Sekolah Pimpinan Nasional) tingkat 1 angkatan 1, DIKLATPIM (Pendidikan dan Pelatihan Kepemimpinan) tingkat 1 angkatan IX, kemudian tahun 2003 mengikuti PEN (Pengembangan Ekslusif Nasional) KSA XII. Disamping itu ia juga menjabat sebagai Eselon 1 dengan program utama mensosialisasikan program kebijakan pemerintah yang memfokuskan penyadaran terhadap mindset masyarakat yang kental dengan patriarkhi agar berubah menjadi pemahaman equal atau berkeadilan antara laki-laki dan perempuan.

Zaitunah juga pernah mendapat kesempatan tugas negara bersama Presiden Gus Dur, Megawati Soekarnoputri, dan Susilo Bambang Yudoyono serta bersama empat menteri yaitu Khofifah Indarparawansa, Sri Rejeki, Mutia Hatta dan Linda Agum Gumelar. Selain itu ia pernah melakukan sebuah penelitian baik dalam maupun luar negeri dengan tujuan pemberdayaan perempuan. Diluar negeri misalnya Mesir, Saudi Arabia,

\footnotetext{
54 Tafsir Kebenian, 257.

55 Zaitunah Subhan, Membina Keluarga Sakinah (Yogyakarta: LKis, 2004), 81.

${ }^{56}$ Ibid., 257.
}

123 | Muṣhaf: Jurnal Tafsir Berwawasan Keindonesiaan Volume 1. Nomor 1, Desember 2020. 
Penafsiran Zaitunah Subhan Dan Aminah Wadud Tentang Kebebasan Perempuan,

Turki, India, Thailand, Malaysia, Cina, Filipina, Australia, Inggris dan Amerika. ${ }^{57}$

Pada tahun 2013, Zaitunah kembali ke tanah air, untuk melanjutkan tugas ilmiah sebagai Guru Besar di UIN Syarif Hidayatullah Jakarta dan mendapat tugas melakukan penelitian internasional "(Sabbatical leave) dengan tema "The Gender Equity in Al-Qur'an Interpretation." Melalui penelitian ini Zaitunah berkesempatan mengelilingi Andalusia-Spanyol (Granada, Cordoba dan Sevilla).

\section{Karya-Karya}

Senada dengan Amina Wadud, sebagai seorang akademisi Zaitunah Subhan juga sangat produktif dalam mengahsilkan karya-karya ilmiah baik berupa artikel maupun buku. Berikut merupakan karya tulis yang telah dipuplikasikan. Karya Terkait Gender adalah Tafsir Kebencian: Studi Bias Gender dalam Tafsir Qur'an (1999), Qur'an dan Perempuan: Menuju Kesetaraan Gender dalam Penafsiran (2015), Penciptaan Wanita dalam Tradisi Sunni (1999), Studi Konperehensi Wanita Karier dan Wanita Rumah Tangga (1994), Kemitrasejajaran Pria dan Wanita di dalam Islam (1997), Ar Rijalu Qawwamuna 'Alan Nisa'(1999), Membina Keluarga Sakinah Melalui Kemitrasejajaran Pria dan Wanita (2000), Kesetaraan dan Keadilan Gender dalam Membangun Good Governance (2001), Kesetaraan dan Keadilan Gender dalam Agama-agama Islam, Kristen/Katholik, Buddha, dan Hindu) 2002, Rekonstruksi Pemahaman Gender dalam Islam (2002), Urgensi Tafsir bi al-Ma'tsur dan bi al-Ra'yi dalam Studi Gender dan Aplikasinya (2002), Membina Keluarga Sakinah (2004), Perempuan dan Politik. dalam Islam (2004), Kondrat Perempuan Takdir atau Mitos? (2004), Kekerasan Terhadap Perempuan (2004), Menggagas Fikih Pemberdayaan Perempuan (2008), Mengoptimalkan Peran Perempuan dalam Membangun Bangsa (2008), Gender and Islam in Indonesia (2008), Bangkitlah Indonesiaku, Memformat Kriteria Pemimpin Bangsa (Mencari Solusi Terbaik Pemberdayaan Perempuan dalam Berbagai Perspektif, 2009), Women Empowerment Issue in Islam (2012), Indabnya Monogami (2013).

\section{Metodologi Tafsir Zaitunah Subhan}

Dalam ranah ilmu tafsir, kita mengenal empat metode yang biasa digunakan oleh para mufassir dalam menggali makna teks al-Qur'an yaitu: tạ̣līi (analitis), ijmālì (global), muqāran (kompartif) dan maudū'ì (tematik). ${ }^{58}$ Dari keempat metode tersebut Zaitunah lebih memilih metode maudù' $\bar{\imath}$ atau tematik sebagai alat dalam memahami teks al-Qur'an. Tafsir maudū' merupakan sebuah metode tafsir yang menghimpun seluruh ayat al-Qur'an

${ }^{57}$ Ibid., 473.

${ }^{58}$ Nashruddin Baidan, Metode Penfsiran al-Qur'an (Yogyakarta: Pustaka Pelajar, 202), 54.

124 | Muṣhạaf: Jurnal Tafsir Berwawasan Keindonesiaan Volume 1. Nomor 1, Desember 2020. 
Penafsiran Zaitunah Subhan Dan Aminah Wadud Tentang Kebebasan Perempuan,

mengenai tema tertentu meskipun tempat, waktu dan sebab turunnya berbeda satu sama lain. ${ }^{59}$ Hal ini senada dengan apa yang dikatakan oleh Quraish Shihab bahwasanya, tafsir maudhu'i merupakan salah satu metode tafsir yang praktis/instan, karena langsung terkait dengan tema tertentu dengan menggunakan ayat al-Qur'an yang lain sebagai pendukung, kemudian mengaitkan dengan berbagai macam disiplin ilmu seperti ilmu munasabah, asbabun nuzul, ilmu lughah dan lain-lain. ${ }^{60}$

Dalam penggunaan tafsir maudhu'i, terdapat dua bentuk penyajian yakni Pertama, menyajikan kotak (meminjam istilah Quraish Shihab) yaitu berisi pesan-pesan al-Qur'an yang terdapat pada ayat yang terangkum pada satu surat saja. Kedua, menghimpun pesan-pesan dalam berbagai surat yang berkaitan. Zaitunah sendiri memilih bentuk yang kedua ini. ${ }^{61}$ Menurut Zaitunah Subhan, penggunaan metode maudhu'i dalam menafsirkan alQur'an memiliki keistimewaan bukan hanya dalam hal kecepatan menyelesaikan suatu persoalan akan tetapi melalui metode ini mufassir mengundang al-Qur'an untuk berbicara secara langsung menyangkut problem yang dialami masyarakat. Sebagaimana yang pernah dikatakan 'Alī bin Abī Tạalib "Persilahkan al-Qur'an berbicara."

Adapun langkah-langkah yang ditempuh Zaitunah dalam penafsirannya adalah; (1) Memakai metode maudù '̌ dengan mengelompokkan ayat-ayat dalam topik tertentu; (2) mendeskripsikan pemikiran-pemikiran para mufassir atau intelektual mengenai ayat-ayat yang telah dikelompokkan; (3) mencari hadist-hadist yang ada kaitannya dengan yang akan diteliti guna memperkuat tema yang dikaji; (4) membuat kesimpulan dengan analitis keritis. $^{62}$

\section{Pemikiran Amina Wadud dan Zaitunah Subhan Tentang Tafsir Bias Gender \\ Perspektif Amina Wadud}

Amina Wadud terkenal sebagai intelektula muslim progresif. Ia hidup dalam lingkungan yang mayoritas masyarakatnya mengaggap laki-laki sebagai superior. Partisipasi perempuan lebih dibatasi daripada laki-laki. salah satu penyebab terjadinya perlakuan selain kultur sosial adalah doktrin para mufassir klasik yang cenderung mendominasi peran laki-laki dari pada

\footnotetext{
59 Su'aib Muhammad, Tafsir Tematik: Konsep, Alat Bantu, dan Contoh Penerapannya (Malang: UIN MALIKI Press, 2013), 17.

${ }^{60}$ Quraish Shihab, Wawasan Al-Qur'an: Tafsir Mudhu'i atas Pelbagai Persoalan Umat (Bandung: Mizan, 1996), 16.

${ }^{61}$ Zaitunah Subhan, Tafsir Kebencian, 14.

${ }^{62}$ Ibid., 14
}

125 | Muṣhaf: Jurnal Tafsir Berwawasan Keindonesiaan Volume 1. Nomor 1, Desember 2020. 
perempuan. Dalam hal ini ia membaginya menjadi tiga kategori: pertama, Tradisionalis. Tafsir tradisional menurut Amina adalah sebuah tafsir yang menafsirkan keseluruhan isi al-Qur'an mulai dari era klasik sampai modern. Tafsir kalsik cenderung menafsirkan ayat al-Quran secara keseluruhan, kemudian mengkaitkan seluruh ayat al-Qur'an dengan hukum, nahwu, sharraf, sejarah, balaghah dan lainnya. Metodologi semacam ini Amina menyebutnya "metodologi atomistik" ${ }^{63}$ lebih jauh ia mengatakan bahwa penggunaan metodologi atomistik kurang atau bahkan tidak ada sama sekali dari mufassirnya untuk mengenali lebih jauh hubungan ayat al-Qur'an dengan tema yang dimaksud. ${ }^{64}$

Selain mengkritisi metodologi para mufassir klasik, Amina juga menyayangkan bias gender dalam tafsir-tafsir klasik yang memprioritaskan laki-laki sebagai superior sedangkan perempuan sebagai inferior. Menurutnya adanya nuansa bias gender dalam tafsir klasik disebabkan oleh sang mufassir seorang laki-laki yang otomatis nuansa didalamnya adalah nuansa laki-laki.

Kedua, Reaktif. Kategori ini biasanya terdapat dalam karya-karya pemikir modern seperti kaum feminisme dan rasionalis. Reaksi ini muncul sebagai bentuk keprihatinan terhadap prilaku diskriminatif terhadap kaum perempuan yang disebabkan oleh penafsiran terhadap teks al-Qur'an. Sebagai contoh karya Fatma A. Sabba dalam bukunya "Women in the Muslim Unconscious". Karya tersebut menurut Amina gagal dalam membedakan antara al-Qur'an dengan tafsiran isi al-Qur'an walaupun dalam pembahasannya sesuai dengan isu saat ini. ${ }^{65}$

Ketiga, Holistik. Amina wadud memposisikan dirinya dalam kategori ini. Dimana interpretasi yang dilakukan mempertimbangkan seluruh metode penafsiran dengan mengaitkan pada persoalan sosial, moral, ekonomi, dan politik modern termasuk persoalan perempuan. Kategori ketiga ini merupakan kategaori yang terbaik menurut Amina Wadud. ${ }^{66}$

Berangkat dari asumsi bahwa al-Qur'an merupakan sumber tertinggi yang memperlakukan laki-laki dan perempuan dengan adil atau setara. Amina mencoba merekonstruksi tafsir-tafsir yang sarat akan bias patriarkhi sehingga relevan sesuai dengan era sekarang. Dalam menafsirkan al-Qur'an, pemikirannya banyak dirpengaruhi oleh Fazlur Rahman terutama dalam segi

63 Tidak ada keterangan lebih mendetail terkait metodologi atomistik dalam karya-karya Amina Wadud, namun dalam sebuah situs online menjelaskan atomistik adalah pola berfikir secara parsial dengan cara memisahkan satu bagian dengan bagian yang lainnya. Atomistik merupakan lawan kata dari holistik. Lihat http:// fawwazmuhammad.tumbir.com/post/16/92312678032/atomistik

${ }^{64}$ Ibid., 2

65 Ibid., 3

${ }^{66}$ Ibid., 4

126 | Muṣhaf: Jurnal Tafsir Berwawasan Keindonesiaan Volume 1. Nomor 1, Desember 2020. 
metodologi. Adanya pengaruh tersebut diakui oleh Amina Wadud dalam bukunya Qur'an and Women. ${ }^{67}$ Menurutnya, dalam menafsirkan al-Qur'an, seorang mufassir harus memperhatikan konteks sosio historis suatu ayat dan baground dari seorang mufassir secara lebih spesifik serta analisis susunan bahasa al-Qur'an yang mempunyai makna ganda. Hal ini penting dilakukan karna sangat mempengaruhi hasil dari suatu penafsiran. ${ }^{68}$

\section{Perspektif Zaitunah Subhan}

Pada dasarnya baik Amina Wadud ataupun Zaitunah Subhan sama-sama sepakat dalam melakukan interpretasi ulang terhadap tafsir-tafsir klasik bias gender. Hanya saja metode atau caranya yang berbeda-berbeda. Amina memilih metode hermeneutika sebagai basis penafsirannya sedangkan Zaitunah Subhan menggunakan metode tematik. Menaggapi fenomena tafsir bias gender yang memandang kaum perempuan adalah makhluk lemah, membuat Zaitunah terdorong untuk membedah wacana-wacana kalsik dengan cara menginterpretasikan ulang kitab suci al-Qur'an dan sabda Nabi yang selama ini dinaggap kaku, baku, serta tidak bisa diganggu gugat penafsiran dan pemahamnnya.

Doktrin tersebut menurut Zaitunah sampai sekarang masih berkembang dan bahkan telah mendarah daging terpatri dalam benak masyarakat. Lebih lanjut ia mengatakan bahwa ketimpangan tersebut terjadi lantaran kurangnya pemahaman para mufassir terhadap istilah apa yang disebut "kodrat perempuan" yang selama ini sering dihubungkan dengan norma agama. Agama dianggap telah melegitimasi terhadap peran perempuan dan diyakini sebagai given (pemberian) Yang Maha Pencipta Allah. ${ }^{69}$

Dalam kaitannya dengan persoalan diatas, al-Qur'an sendiri memiliki beberapa potensi dalam menyebabkan adanya multi penafsiran diantaranya, kosak kata bahasa Arab (bahasa yang digunakan al-Qur'an) sering kali bermakna tidak tunggal sehingga terkadang dinilai bias gender, pembakuan tanda huruf, tanda baca, qiraah, pengertian kosakata (mufradat), menetapkan rujukan kata ganti (dlamir), istisna (batas pengecualian), arti huruf-huruf 'atf, bias dalam struktur bahasa (Arab), biasa dalam kamus bahasa Arab, bias dalam metode tafsir, dan pengaruh adanya Israiliyat. $^{70}$

\section{Tafsir Kebebasan Perempuan Menurut Amina Wadud}

\footnotetext{
${ }^{67}$ Ibid., 5

${ }^{68}$ Ibid., 7.

${ }^{69}$ Zaitunah Subhan, Qur'an dan Perempuan, 33.

${ }^{70}$ Ibid., 34.
}

127 | Muṣhạa: Jurnal Tafsir Berwawasan Keindonesiaan Volume 1. Nomor 1, Desember 2020. 
Sebagai salah satu tokoh feminisme muslim, Amina sangat menetang anggapan-anggapan stigmatik terhadap perempuan yang selama ini membudaya di masyarakat. Menurutnya, anggapan bahwa seorang perempuan merupakan makhluk yang "rendah atau tidak sederajad" adalah cerminan dari kedangkalan sikap kaum muslimin. Padahal al-Qur'an sendiri nyatanya memperlakukan perempuan sebagai individu sebagaimana laki-laki, yang membedakan hanya dalam hal "taqwa". ${ }^{71}$ Walaupun begitu, tidak dapat dipungkiri al-Qur'an dalam beberapa ayatnya mengakui adanya perbedaan fungsional antara laki-laki dan perempuan seperti, melahirkan dan menyusui yang sepenuhnya menjadi kodrat dari seorang perempuan. ${ }^{72}$ Perbedaan fungsional tersebut seringkali dijadikan gagasan untuk mendukung superioritas inheren laki-laki di atas perempuan.

Dalam al-Qur'an terdapat sekitar 27 ayat tentang gender, namun tidak seluruhnya menadapat perhatian serius oleh Amina. Salah satu ayat yang menjadi perhatian seperti, kepemimpinan, nuzyuz, talaq serta kebebasan perempuan dalam mengaktualisasikan dirinya. Pertama, Kepemimpinan Dalam Rumah Tangga. Pembahasan terkait kepemimpinan perempuan memang menjadi isu kontroversial sampai sekarang. Salah satu ayat yang sering dijadikan rujukan dalam membelenggu kebebasan perempuan adalah permasalahan kepemimpinan adalah QS. al-Nisā' ayat 34. Secara tradisional, ayat tersebut dipandang sebagai salah satu ayat yang paling penting perihal hubungan laki-laki dan perempuan. Lafal "qawwàmūna 'alà alnisă" dalam ayat diatas menurut Amina dapat diterapkan apabila memenuhi dua syarat: Pertama, "pelebihan" seperti apa yang diberikan. Kedua, mereka membiayai hidup perempuan dari harta mereka. Namun apabila kedua syarat tersebut tidak dapat terpenuhi maka, laki-laki tidak "qawwām" atas perempuan. Hal ini didasarkan pada pengguanaan kata bi pada lafal fadala.

Dalam ilmu gramatikal kata bi menunjukkan bahwa karakteristik atau isi sebelum bi ditentukan "berdasarkan" apa yang disebutkan setelah $b i{ }^{73}$ Oleh sebab itu, Amina memusatkan penafsirannya pada lafad fadala yang menurutnya, kalimat tersebut mengandung arti adanya keterkaitan antara laki-laki dan perempuan untuk saling melengkapi. ${ }^{74}$ Selain itu, lafal fadala pada ayat diatas diikuti oleh kalimat " $b a$ '

\footnotetext{
${ }^{71}$ Amina Wadud, Al-Qur'an Menurut Perempuan, 110.

${ }^{72}$ Ibid, 110

${ }^{73}$ Huruf $b a$ ' dalam lafadz "bima fadhala" merupakan $b a$ ' sababiyyah yang dikenal dalam bahasa Arab bi yang berfungsi untuk suatu alasan dan tujuan. Kata ini menetapkan suatu hubungan bersyarat diantara dua bagian kalimat atau anak kalimat. Lihat Jalaluddin Muhammad bin 'Abdullah bin maliki, Syarah Ibnu 'Aqil 'ala Alfiah, (Surabaya: Dar al-Ilmu, $\mathrm{tt}), 99$.

${ }^{74}$ Ibid., 122.
}

128 | Muṣhaf: Jurnal Tafsir Berwawasan Keindonesiaan Volume 1. Nomor 1, Desember 2020. 
(mereka) ataupun jamak feminin sehingga mengandung makna tidak semua laki-laki lebih baik daripada perempuan dalam segala hal. Bisa saja laki-laki dilebihkan dalam hal tertentu saja, begitu pula perempuan lebih baik dari laki-laki dalam beberapa hal. Untuk itu, tidak ada kelebihan yang benar-benar bersifat absolut. $^{75}$

Berbeda dengan salah seorang mufassir kontemporer Sayyid Quthb yang mengatakan bahwa qawwämah merupakan perkara yang berhubungan dengan keluarga di dalam masyarakat. Oleh sebab itu, ia membatasai ayat tersebut hanya dalam konteks hubungan suami istri dimana seorang laki-laki yang memberikan nafkah kepada istrinya berupa materi, mempunyai hak untuk qawwāmūn atas istrinya. ${ }^{76}$ Amina Wadud cenderung menafsirkan ayat tersebut tidak hanya terbatas pada ruang lingkup keluarga saja. Akan tetapi juga dapat berimplikasi pada masyarakat secara umum. Penafsiran ini terinspirasi dari pola hubungan fungsional suami istri sebagaimana yang terdapat dalam penafsiran Sayyid Quthb.

Menurut Amina Wadud pola hubungan fungsional tersebut juga berdampak pada terbentuknya masyarakat secara umum. Dalam sebuah keluarga setiap anggota mempunyai tanggung jawab tertentu seperti melahirkan kerurunan bagi perempuan. Dalam kaitannya dengan masyarakat, secara tidak langsung perempuan telah ikut serta dalam membangun sebuah masyarakat dengan melahirkan generasi (anak) penerus bangsa. Tanggung jawab ini memerlukan kekuatan fisik, stamina, kecerdasan dan komitmen personal. Sedangkan laki-laki bertanggung jawab dalam memberikan perlindungan fisik, material serta spritual, moral, intelektual dan psikologis. Tugas inilah yang kemudian di dalam al-Qur'an disebut dengan kata qawwàm. Namun, apabila seorang laki-laki tidak dapat memenuhi tanggung jawabnya tersebut maka predikat qawwām tidak pantas disematkan kepadanya. ${ }^{77}$

Dari pemaparan penafsiran Amina diatas penulis berkesimpulan bahwa dalam menafsiri ayat tentang kepemimpinan Amina Wadud menggunakan teori fungsionalis. ${ }^{78} \mathrm{Hal}$ ini berdasarkan penafsirannya yang cenderung menafsirkan ayat tersebut bukan dalam hal superioritas laki-laki atas perempuan akan tetapi, tanggung jawab atau fungsi masing-masing bagi

\footnotetext{
${ }^{75}$ Ibid., 126.

${ }^{76}$ Sayyid Quthb, Fi Zhilal al-Qur'an, (Kairo: Dar al-Syuruq, 1980), jilid II, 650.

${ }^{77}$ Ibid., 127.

78 Teori fungsionalis merupakan sebuah teori yang berangkat dari asumsi bahwa suatu masyarakat terdiri atas berbagai bagian yang saling mempengaruhi. Teori ini bertujuan mencari unsur-unsur mendasar yang berpengaruh dalam suatu masyarakat, mengidentifikasi fungsi setiap unsur, dan menerangkan berbagai fungsi unsur-unsur tersebut dalam masyarakat. Lihat Nasaruddin Umar, Argumen Kesetaraan Gender Perspektif Al-Qur'an (Jakarta: Paramadina, 2001), Cet. II, 51
} 
laki-laki dan perempuan sebagai akar terbentuknya suatu bangsa. Sikap semacam ini menurut penulis dapat meminimalisir paradigma patriarkhi yang selama ini membelenggu kebebasan kaum perempuan.

Kedua, Nushüz. Kata nuz̧üz, sering kali diperuntukan hanya bagi kaum perempuan yang dinilai memiliki sifat ketidak patuhan terhadap suaminya. Ketidak patuhan tersebut seperti, membangkang tanpa adanya alasan yang jelas, dan meninggalkan rumah tanpa izin dari suaminya. QS. al-Nisa' ayat 34 seringkali dijadikan alasan oleh kaum laki-laki dalam membenarkan tindak kekerasan terhadap kaum perempuan khususnya dalam rumah tangga. Anggapan ini didukung oleh kitab-kitab fiqh dan kitab tafsir klasik yang mayoritas menganggap bahwa kata nusyus hanya diperuntukan pada istri yang tidak taat terhadap suaminya. Seorang istri dituntut untuk senantiasa patuh terhadap suaminya, namun menurut Amina Wadud kata nu₹hйz tidak hanya diperuntukan bagi istri akan tetapi juga untuk suami. ${ }^{79}$

Selain ayat di atas, kata Nushūr juga disebut dalam QS. al-Nisā' ayat 128. Ayat tersebut menunjukkan bahwa nuдhйz sesunggguhnya bukan hanya diperuntukan bagi istri akan tetapi juga berlaku bagi suami. Oleh karena itu menurut Amina Wadud kata nuг̧ür sebenarnya merupakan kata yang netral baik laki-laki ataupun perempuan. Oleh karena itu, dalam memaknai kata nuzhür, Amina mengutip pendapat dari Sayyid Qutb yang mengatakan bahwa nuzbür lebih sesuai diartikan sebagai terjadinya ketidak harmonisan dalam suatu pernikahan. Menurutnya makna tersebut merupakan makna yang netral sehingga tidak terkesan bias gender. ${ }^{80}$

Al-Qur'an menawarkan beberapa solusi ketika dalam sebuah rumah

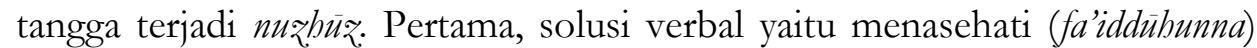
baik secara langsung sebagaimana dalam al-Nisa' ayat 34 atau dengan bantuan penengah seperti dalam al-nisā' ayat 128. Apabila solusi yang pertama gagal maka diberlakukan solusi yang lebih tegas yakni pemisahan atau pisah ranjang. Kemudian langkah terakhir adalah memukul. Langkah ini hanya apabila sudah benar-benar dalam keadaan terdesak.

Dalam menciptakan keharmonisan dalam rumah tangga baik suami atau istri harus memperhatikan hal-hal berikut. Pertama, al-Qur'an sejatinya mengutamakan kondisi harmonis yaitu dalam menyelasaikan sebuah masalah tidak perlu ada percekcokan apalagi tindak kekerasan. Kedua, apabila solusi pertama dilakukan sesuai dengan apa diajarkan al-Qur'an maka sangat mungkin antara kedua belah pihak akan tercapai keharmonisan sebelum menempuh langkah yang terakhir. Ketiga apabila solusi yang ketiga memang harus dilakukan, maka tidak boleh menyebabkan terjadinya kekerasan atau

\footnotetext{
${ }^{79}$ Amina Wadud, Qur'an Menurut Perempuan, 128.

${ }^{80}$ Ibid., 129.

130 | Muṣhạa: Jurnal Tafsir Berwawasan Keindonesiaan Volume 1. Nomor 1, Desember 2020.
} 
Penafsiran Zaitunah Subhan Dan Aminah Wadud Tentang Kebebasan Perempuan,

perkelahian antara keduanya, karena tindakan tersebut sama sekali tidak islami. $^{81}$

Dari ketiga solusi diatas, menurut Amina solusi pertama merupakan solusi yang terbaik dan lebih diutamakan oleh al-Qur'an karena sama-sama dibicarakan oleh kedua ayat (al-Nisā' ayat 34 dan 128). ${ }^{82}$ Sesuai dengan prinsip umum al-Qur'an yakni mushäwarah atau syura' sebagai metode terbaik dalam memecahkan suatu masalah. ${ }^{83}$ Dari sini dapat ditarik kesimpulan bahwa sejatinya al-Qur'an bermaksud memecahkan permasalahan dan kembali pada kedamaian serta keharmonisan di antara kedua belah pihak sebagaimana yang terdapat pada firman terakhir dalam al-Nisa' ayat 128 .

Mengenai solusi yang ketiga yakni kata daraba (pada ayat fadribūhunna), kata tersebut menurut Amina mempunyai banyak makna, tidak harus berarti memukul. Dalam Lisan al-Arab sebagaimana yang dikutip oleh Amina Wadud, bahwa makna kata dharaba tidak hanya menyatakan kekerasan atau kekuatan. Misalnya QS. Ibrahim ayat 24. Selain itu, kata dharaba juga bisa berarti 'arada 'anhu wa sarafa (berpaling dan meninggalkan pergi), dan bertindak tegas misalnya daraba al-daulah 'ala al-muta'älibin bi alas'ar (negara bertindak tegas terhadap pihak-pihak yang mempermainkan harga). ${ }^{84}$ Oleh karena itu menurut hemat penulis makna kata dharaba lebih tepat diartikan sebagai sikap tegas. Tegas disini bukan berarti selalu dalam bentuk kekerasan bisa saja dengan mewanti-mewanti dan lain sebagainya. Menurut Hussein Muhammad makna tegas lebih cocok diterapkan dalam konteks kontemporer yang lebih menghargai cara-cara tanpa kekerasan serta relevan dengan wacana kesetaraan dan keadilan gender. ${ }^{85}$

Ketiga, Perempuan dalam Ranah Publik. Berbicara tentang peran perempuan pasti bayangan kita akan tertuju bahwa perempuan identik dengan melahirkan, menyusui dan merawat anak. Peran tersebut dianggap sebagai fungsi utama mereka. Kata utama disini seringkali diayakini bahwa seorang perempuan hanya bisa menjadi seorang ibu. Sehingga banyak dari para orang tua yang memiliki anak perempuan diarahkan pada pembentukan istri dan ibu yang ideal dalam menjalankan fungsinya.

Anggapan diatas menurut Amina Wadud bertentangan dengan apa yang ada dalam teks al-Qur'an. Karena tidak ada satu ayatpun yang membenarkan bahwa tugas sebagai ibu merupakan fungsi utama bagi kaum

\footnotetext{
${ }^{81}$ Ibid., 130.

${ }^{82}$ Ibid., 131.

${ }^{83}$ Lihat QS. AL-Syura ayat 38.

${ }^{84}$ Muhammad Kamil, Penafsiran Wadribubunna dalam Surat al-Nisa' ayat 35, (Skripsi: UIN Sunan Ampel Surabaya), 17.

${ }^{85}$ Hussein Muhammad, Islam Agama Ramah Perempuan, (Yogyakarta: LKiS, 2004), 250.
}

131 | Muṣhạa: Jurnal Tafsir Berwawasan Keindonesiaan Volume 1. Nomor 1, Desember 2020. 
perempuan. Peran tersebut menjadi utama hanya karena memiliki kesinambungan bagi kelanjutan eksistensi manusia. Al-Qur'an sendiri meyatakan penghormatnnya terhadap perempuan atas perannya dalam melahirkan keturunan, sebagaimana dalam surat al-Nisā' ayat $1 .^{86}$

Peran sebagai seorang ibu, seringkali diwarnai dengan stigma negatif yang cenderung membatasai ruang gerak perempuan hanya berkutat pada ranah domestik saja. Salah satu contohnya adalah masalah kepemimpinan, laki-laki dianggap lebih pantas menjadi seorang pemimpin baik dalam ranah keluarga maupun dalam masyarakat. Hal ini dikarenakan laki-laki dianggap lebih memiliki keistimewaan didepan publik serta pengalaman dan keunggulan lainnya. namun hal ini terjadi pada masa kondsi sosial pada sistem partiarki Arab masa lampau.

Meskipun dalam budaya masyarakat terdapat perbedaan peran baik laki-laki dan perempuan bahkan pada masa turunnya wahyu, sejatinya menurut Amina Wadud tidak ada pernyataan tersirat maupun tersurat dalam al-Qur'an yang mengatakan bahwa otoritas sebagai pemimpin hanya diperuntukan bagi laki-laki. Sebaliknya al-Qur'an dalam konteks negri Saba' dimana pada waktu itu sangat kental dengan budaya patriarkhi malah memunculkan seorang penguasa perempuan yakni ratu Balqis. Ia digambarkan dengan sangat baik di dalam al-Qur'an. Sebagaimana penjelasan pada bab sebelumnya. ${ }^{87}$

\section{Tafsir Kebebasan Perempuan Perspektif Zaitunah Subhan Kepemimpinan dalam Keluarga}

Jika Amina Wadud menafsirkan al-Nisā’ ayat 34 sebagai hubungan fungsional antara laki-laki dan perempuan, maka Zaitunah Subhan menafsirkan ayat tersebut sebagai pengayom, penopang, penanggung jawab atau penjamin (dalam hal kewajiban memberi nafkah terhadap istrinya.). lebih lanjut Zaitunah mengatakan kata pemimpin kurang pantas apabila dikaitkan dengan hubungan suami istri dalam rumah tangga, karena tugas rumah tangga harus melibatkan keduanya baik laki-laki atau perempuan. Gelar Pemimpin merupakan kata terakhir yang diperlukan oleh keluarga ketika terjadi perselisihan atau penyelesaian dalam menentukan pilihan yang akan ditetapkan atau diputuskan. Sehingga kepemimpinan dalam keluarga merupakan kepemimpinan berdasarkan musyawarah bukan berdasarkan

\footnotetext{
${ }^{86}$ Hai manusia, bertakwalah kepada Allah yang dengan nama-Nya kamu meminta bak satu sama lain, dan (bormatilab) rabim (yang melabirkanmu).

${ }^{87}$ Amina Wadud, Qur'an Menurut Perempuan, 153.
}

132 | Muṣhạa: Jurnal Tafsir Berwawasan Keindonesiaan Volume 1. Nomor 1, Desember 2020. 
kesewenagan. ${ }^{88}$ Hal ini semakin jelas apabila melihat dari asbāb al-nuzūl ayat yang turun berkenaan dengan masalah keluarga. ${ }^{89}$

Penetapan kaum laki-laki sebagai pemimpin berdasarkan redaksi surat al-nisa' ayat 34 bukan merupakan pernyataan normatif akan tetapi, pernyataan kontekstual. Hal ini Karena, pertama al-Qur'an hanya mengatakan laki-laki adalah qawwām (dalam ilmu gramatikan lafal qawwām merupakan susunan mubtada' khabar) tidak ada indikasi yang mengharuskan laki-laki qawwämun (pemimpin) atas perempuan. Sehingga baik laki-laki ataupun perempuan keduanya mempunyai kesempatan yang sama dalam menjadi pemimpin. Kedua, berkaitan dengan alasan-alasan yang diungkapkan dalam teks ayat tersebut sebagai pembenar superioritas laki-laki sebagai pemimpin diantaranya, bahwa laki-laki diberikan kelebihan oleh Allah dari pada perempuan. Kelebihan tersebut menurut Quraish Shihab berupa fisik dan psikis yang ada pada diri seorang laki-laki. ${ }^{90}$ Rasyid Riddlo dalam tafsirnya mengatakan kelebihan tersebut berdasarkan sebab fitri dan kasbi. fitri (bawaan) dalam artian sejak awal mula penciptaan perempuan diberikan fitrah untuk mengandung, melahirkan serta mendidik anak-anaknya. Sedangkan laki-laki semenjak penciptaannya telah diberikan kekuatan dan kemampuan (akal) baik dalam hal berinovasi dan usaha disegala bidang (kasbi). ${ }^{91}$ Kemudian alasan selanjutnya karena laki-laki telah menafkahkan harta mereka kepada perempuan (istrinya).

Alasan-alasan tersebut diatas menurut Zaitunah pada zaman sekarang tidak bisa dijadikan tolak ukur keunggulan laki-laki sebagai pemimpin kaum perempuan. Semuanya bisa berubah seiring dengan perkembangan zaman. Hal ini terbukti dengan banyaknya perempuan yang mempunyai kekuatan bahkan kecerdasan akal yang setara dengan laki-laki atau bahkan melebihi kaum laki-laki. Bagitu juga dalam hal pemberian nafkah, sebagai tanggung jawab laki-laki (suami) kepada perempuan (istri). Kewajiban ini bukan merupakan perbedaan hakiki melainkan perbedaan

${ }^{88}$ Zaitunah Subhan, Tafsir Kebencian, 108.

89 Ayat tersebut turun dikarenakan Istri Sa'ad bin Rabi'yang tidak taat pada suaminya. Kemudian Sa'ad menamparnya. Lalu istri Sa'ad Habibah bin Abi Zubair mengadu kepada Rasulullah dan Rasulullah memerintahkan kepada Habibah untuk menbalas perlakuan suaminya terhadap Habiba Katika Habubah pergi Rasulullah memanggilnya dan bersabda, "Jibril datang kepadaku" kemudian Allah menurunkan ayat "kaum laki-laki adalah pemimpin bagi kaum perempuan." Selanjutnya Rasullullah bersabda "Ia menginginkan sesuatu tapi Allah berkehendak lain." Lihat Ahmad al-Wahidi, Asbabun Nuzul al-Qur'an, (Kairo: Dar al-Kitab al-Jadid, 1969), 144.

${ }^{90}$ Quraish Shihab, Wawasan al-Qur'an: Tafsir Maudbu'i atas Pelbagai Persoalan Umat, Jakarta: Mizan,1996), 310.

${ }^{91}$ Rasyid Ridlo, Tafsir al-Manar, Jilid V (Mes ir: Al-Haiah al-Misriyyah, 1973), 67.

133 | Muṣhạa: Jurnal Tafsir Berwawasan Keindonesiaan Volume 1. Nomor 1, Desember 2020. 
fungsional saja. Artinya apabila sorang istri secara ekonomi dapat mandiri baik dari harta waris atau berpenghasilan sendiri, kemudian memberikan penghasilannya untuk kepentingan keluarganya maka, kelebihan dan keunggulan suami menjadi berkurang karena ia tidak memiliki keunggulan dalam bidang ekonomi. ${ }^{92}$

Disamping itu, mengacu pada istilah yang digunakan dalam surat alNisa' ayat 34 daiatas, dalam menggambarkan laki-laki dan perempuan adalah kata rijäl (laki-laki) dan nisa' (perempuan). Kata tersebut menurut AlAshfahani dapat berubah maknanya apabila ditinjau dari aspek sosiologisnya dalam arti, makna kata rajul dapat berganti perempuan apabila aktivitas perempuan menyerupai laki-laki seperti mencari nafkah dan lain-lain. Dan begitupun sebaliknya. ${ }^{93}$

Dengan melihat makna dari pada istilah-istilah yang digunakan dalam gender khususnya yang berkaitan degan ayat kepemimpinan, menunjukkan bahwa makna dari sebuah kata mempunyai sifat elastis dan dinamik bahasa, sehingga menurut penulis, merupakan suatu hal yang wajar apabila sebuah penafsiran tidak pernah mengahasilkan pemahaman yang tunggal.

\section{Nuzhūs}

Melihat dari objek kata nuð̧ūz dalam surat al-Nisā’ ayat 34, Zaitunah Subhan mempunyai pandagan yang sama dengan Amina Wadud yaitu, nuz̧й zukan hanya diperuntukan bagi perempuan (istri) akan tetapi juga bisa dilakukan oleh laki-laki (suami). Lebih lanjut ia megatakan bahwa pemahaman tentang nuzbüz tidak bisa dilakukan secara sepihak tanpa melihat akar permasalahan yang mendasarinya. Sebab bisa saja seorang yang melakukan nuzhür. mempunyai alasa-alasan sehingga ia berbuat demikian. Hal ini berdasarkan pendapat ulama seperti Imam Nawawi yang mengatakan penolakan istri untuk melayani kewajibannya terhadap suami dapat diaktegorikan nuzhür. apabila terdapat unsur kesengajaan atau tanpa didasari alasan yang dibenarkan oleh shara. Al-Syaukani menambahkan nuд̧üz hanya berlaku apabila sang suami tidak berlaku aniaya dan mendzalimi istrinya. ${ }^{94}$

Nuzhür menurut Zaitunah Subhan merupakan pembangkangan istri terhadap suaminya. Makna tersebut dikhususkan terkait relasi manusia dan tuhannya, misalnya seorang suami meminta istrinya melakukan hal-hal baik seperti shalat, puasa dan lain-lain namun, sang istri menolak. Kemudian mengenai penolakan seorang istri dalam memenuhi kenutuhan biologis

\footnotetext{
92 Zaitunah Subhan, Tafsir Kebencian, 109.

${ }^{33}$ Al-Ashfahani, al-Mufradat fi Garib al-Qur'an, (Mesir: Mushtafa al-Halabi, 1961), 190.

${ }^{94}$ Zaitunah Subhan, Al-Qur'an dan Perempuan, 187.
} 
suaminya, tidak bisa serta merta melegitimasi bahwa istri telah nuғyuz. terhadap suaminya. ${ }^{95}$

Adapun penyelesaiannya apabila terjadi nu₹hйz menurut Zaitunah dilakukan secara bertahap dari menasehati, kemudian pisah ranjang ataun tidak menggaulinya dan yang terakhir memukul dengan pukulan yang tidak melukai. Perihal solusi yang terakhir yakni diperbolehkannya memukul istri, Zaitunah mengutip pendapat dari Ibnu 'Arabī yang bahwasanya Ibnu 'Arabi lebih mengartikan pemaknaan memukul secara kontekstual. Dengan kata lain Ibnu 'Araby menolak pemakaan kata daraba secara harfiah atau literal.

Kata daraba sendiri dalam al-Qur'an terdapat dalam beberapa surat dengan makna yang berbeda-beda salah satu contohnya dalam surat Ibrahim ayat 24 sebagaimana penulis singgung diatas, mempunyai makna pergi dalam surat al-Nisa' ayat 34, mengadakan pada al-Nahl ayat 74, seerta bermakna menutup dalam surat al-Nūr ayat 3. Dalam hal ini Zaitunah memaknai kata dharaba dengan "mengacuhkan."Mengacuhkan disini dalam arti suami tidak memberi nafkah lahir ataupun batin. Hal ini berdasarkan hadist Nabi bahwasanya Rasulullah bersabda:

Aku heran terhadap seorang yang memukul istrinya. Dialah yang semestinya lebih layak untuk dipukul. Jangan kalian memukul istri kalian dengan kayu karena akibatnya adalah kalian akan diqishas. Kalian dapat memutuskan untuk tidak memberikan istri kalian nafkah sehari-harinya. Perbuatan ini lebih bermanfaat bagi kalian di dunia dan akhirat. ${ }^{96}$

Kata daraba dalam arti mengacuhkan menurut Zaitunah lebih sesuai karena, dengan suami benar-benar tidak melakukan hubungan dengan istrinya secara total, secara otomatis sang istri akan merasa tidak diperhatikan lagi sebagai salah satu anggota keluarga. Solusi ini diharapkan dapat membuat istri sadar akan tanggung jawabnya sebagai seorang istri. ${ }^{97}$

\section{Perempuan dalam Ranah publik}

Zaitunah berpendapat bahwa al-Qur'an tidak melarang perempuan berkuasa, baik atas perempuan maupun atas laki-laki. Namun memilih orang yang paling cocok untuk mengemban tugas tertentu merupakan suatu proses yang dinamis. Seorang perempuan yang lebih independen dan berwawasan luas mungkin akan lebih baik. ${ }^{98}$

\footnotetext{
95 Ibid., 189.

${ }^{96}$ Ibid., 197.

${ }^{97}$ Ibid., 198.

98 Zaitunah Subhan, Tafsir Kebencian, 170
}

135 | Muṣhaf: Jurnal Tafsir Berwawasan Keindonesiaan Volume 1. Nomor 1, Desember 2020. 
Nama R.A Kartini, Nyai Ahmad Dahlan sudah tidak asing lagi bagi kita, khususnya masyarakat Indonesia. Mereka adalah perempuanperempuan hebat pencetus emansiapasi wanita yang sukses membebaskan kaum perempuan dari belenggu norma-norma agama yang bersifat patriarkhi terhadap kaum perempuan sesuai dengan ajaran Islam yang sesungguhnya. Kemudian Rohana Kudus, seorang jurnalis perempuan pertama yang menyandang gelar pahlawan nasional karena kiprahnya dalam membantu tercapainya kemerdekaan di Indonesia, serta jasanya dalam mendirikan sekolah pertama bagi kaum perempuan.

Pesatnya kemajuan teknologi mengubah mindset kaum perempuan dalam mengembangkan konsep dirinya. Dengan konsep inilah ia bisa mengatur strategi dalam menyikapi lingkungannya. Konsep tersebut meliputi kesadaran bahwa manusia adalah khalifah Tuhan, konsep bekerja dan berdedikasi (pengabdian) yang didalam istilah agama disebut ibadah. Ibadah dalam hal ini bukan hanya shalat, puasa dan haji, akan tetapi melainkan berusaha mencari kehidupan untuk keperluan diri, keluarga dan sebagainya. ${ }^{99}$

Dalam konteks perbedaan biologis dimana seorang perempuan dituntut untuk senantiasa berada di dalam rumah merawat dan melayani suaminya. Zaitunah Subhan mengutip pendapatnya Abu Syuqqah tentang kaum perempuan. Dalam hal ini Abu Syuqqah mengutip hadist yang diriwayatkan oleh Siti "Aisyah yang mengatakan "wanita yang paling panjang tangannya adalah Zainab, sebab ia bekerja dengan tanganya sendiri dan bersedekah." Hadis tersebut menunjukkan bahwa seorang wanita mampu memenuhi kebutuhan hidupnya serta keluarganya tanpa bantuan dari suaminya. ${ }^{100}$

Selain perbedaan biologis, menurut Zaitunah, ayat-ayat al-Qur'an serta hadits yang sering menjadi alasan perempuan dilarang berkarir di luar rumah atau publik, seperti bekerja, berpolitik, dan lainnya adalah QS. alAhzab ayat 33, ${ }^{101}$ al-Nisa' ayat $34^{102}$ dan Hadits Nabi yang diriwayatkan oleh Abi bakrah ${ }^{103}$. Hal ini juga diperkuat oleh pendapat Hamka bahwasanya ayat

\footnotetext{
${ }^{99}$ Zaitunah Subhan, Tafsir Kebencian, 164.

100 Ibid, 167

101 Artinya Dan hendaklah kamu tetap di rumahmu dan janganlah kamu berhias dan bertingkah laku seperti orang-orang jahiliyah terdahulu.

102 Artinya kaum pria adalah pemimpim kaum wanita oleh karena Allah telah melebihkan sebahagian mereka (kaum laki-laki) atassebagian yang lain (kaum perempuan), dan mereka (kaum laki-laki) telah menafkahkan harta mereka.

103 Artinya, tidak akan bahagia suatu bangsa apabila yang memimpin itu wanita. Hadits ini tidak bisa dijadikan hujjah tentang larangan perempuan menjadi seorang pemimpin. Dengan alasan hadits tersebut berkaitan dengan kasus tertuntu. Yakni terkait dengan pengangkaytan putri raja Kisra di Negeri Persia. Karena putri raja tersebut diangkat menjadi ratu/pemimpin tanpa satu keahlianpu. Jadi hadits tersebut, tidak bisa digeneralisir untuk semua kaum perempuan yang memiliki potensi lebi
}

136 | Muṣhaf: Jurnal Tafsir Berwawasan Keindonesiaan Volume 1. Nomor 1, Desember 2020. 
al-Ahzab ayat 33 tersebut bukan hanya berlaku kepada istri-istri nabi saja, namun juga untuk menjadi pedoman bagi setiap wanita muslimah. Namun, beda halnya dengan Ali Asghar Engieer yang berpendapat bahwa pandangan seorang perempuan harus menjaga rumah serta merawat anak-anaknya adalah pandangan yang tidak sesuai dengan maksud dan tujuan al-Qur'an. Pendapat Ali Asghar tersebut dikomentari oleh Zaitunah Subhan bahwasanya, hal itu bukan berarti wanita tidak bisa berdedikasi penuh untuk keluarganya terutama kepada anak-anaknya, namun agar terjadi balance antara suami istri dalam mengemban tanggung jawab masing-masing.

Bedasarkan pemaparan di atas, dapat disimpulkan bahwasanya tidak ada halangan bagi seorang perempuan untuk berkarir diuar rumah dan berdedikasi kepada keluarga dan masyarakat dengan syarat wanita tersebut dapat menjaga kehormatannya

\section{Persamaan Penafsiran}

Sebagai seorang feminisme tentunya Amina dan Zaitunah pastilah memiliki kesamaan dalam menafsiri ayat. Entah itu berupa metodologi, teori maupun pendekatan. Namun secara umum anatara Amina dan Zaitunah memiliki pandangan yang sama. Adapun persaman yang paling tampak diantara keduanya adalah, pertama, pandangan budaya patriarki terhadap kaum perempuan. Mereka berdua sepakat bahwasanya budaya patriarki bukanlah yang dikehendaki oleh al-Qur'an, karena tidak ada satu ayat-pun yang membenarkan budaya patriarki yang berkembang di masyarakat. ${ }^{104} \mathrm{Al}-$ Qur'an memang mengakui adanya perbedaan antara kaum laki-laki dan perempua namun hal itu, hanya sebatas perbedaan fungsional saja bukan dalam hal menentukan peran bagi setiap individu. Zaitunah Subhan mengatakan perbedaan tersebut berdasarkan pada aspek peran masingmasing dalam tatanan kehidupan. Ia mengumpamakan perbedaan tersebut sebagaimana siang dan malam yang keduanya merupakan satu kesatuan dari ketetapan dan ketentuan Allah. ${ }^{105}$

Kedua, mereka berdua sama-sama ingin megungkapkan prinsip normatif teks al-Qur'an terkait keadilan gender. Hal ini karena realitas yang ada dalam masyarakat, khususnya tentang perempuan masih jauh dari apa yang maksud oleh al-Qur'an. Salah satu penyebabnya adalah pandangan para mufassir klasik yang menafsirkan ayat-ayat al-Qur'an yang terkesan bias pria, sehingga baik Amina maupun Zaitunah Subhan merasa perlu menginterpretasikan kembali penafsiran-penafsiran ulama tradisional agar

104 Amina Wadud Muhsin, Wanita di dalam Al-Qur'an, 12.

105 Zaitunah Subhan, Tafsir Kebencian, 42.

137 | Muṣhaf: Jurnal Tafsir Berwawasan Keindonesiaan Volume 1. Nomor 1, Desember 2020. 
relevan pada masa sekarang. ${ }^{106}$ Sebagai contoh dalam hal penafsiran mengenai ayat-ayat terkait kebebasan perempuan seperti, ayat tentang kepemimpinan, nuzyuz dan peran perempuan dalam ranah publik.

Masalah tentang kepemimpinan, keduanya sama-sama menolak bahwa surat al-nisa' ayat 34 merupakan alasan superioritas laki-laki sebagai pemimpin atas perempuan. Zaitunah Subhan mengatakan ayat tersebut bukan berbicara spesifik tentang kepemimpinan akan tetapi masalah kekerasan yang dilakukan oleh suami terhadap istrinya yang seharusnya suami melindungi dan mengayomi. Sedangkan Amina Wadud menasirkan ayat tersebut sebagai hubungan fungsional anatara laki-laki dan perempuan. Dimana hubungan tersebut berdampak pada terbentuknya suatu masyarakat.

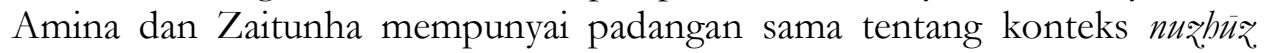
dalam keluarga yaitu perilaku nuə̧ $\bar{u}$, tidak hanya ditujukan untuk kaum perempuan akan tetapi juga laki-laki. Kemudian terkait peran perempuan dalam ranah publik, penafsirkan keduanya mempunyai tujuan yang sama yakni memberi kesempatan seluas-luasnya bagi siapapun yang ingin mengembangkan potensi dirinya.

\section{Perbedaan Penafsiran}

Adapun perbedaan penafsiran yang paling tampak adalah terkait metodologi yang digunakan oleh Amina Wadud dan Zaitunah Subhan. Amina Wadud menggunakan metode hermeneutika yang digagas oleh fazlur Rahaman dalam tafsirnya. Metode ini dalam pengoprasiannya bertujuan untuk memperoleh kesimpulan makna suatu teks atau ayat. Adapaun lagkahlangkahnya sebagai berikut: (1) Dalam konteks apa teks itu ditulis, apabila kaitannya denga al-Qur'an maka yang menjadi fokus perhatian adalah asbabun nuzul ayatnya. (2) Menganalisis bahasa yang digunakan, bagaimana pengungkapannya, sertaa apa yang dikatakan dibalik teks tersebut. (3) Menentukan weltanschaumng-nya atau pandangan dunia. ${ }^{107}$

Sedangkan Zaitunah Subhan memilih menggunakan metode maudü' dalam menafsirkan ayat al-Qur'an. Tafsir maudü $\imath$ (tematik) merupakan sebuah metode tafsir yang menghimpun seluruh ayat al-Qur'an mengenai tema tertentu meskipun tempat, waktu dan sebab turunnya berbeda satu sama lain. Adapun langkah-langkah yang ditempuh dalam tafsir Zaitunah Subhan yaitu: (1) Memakai metode maudūi $\imath$ dengan mengelompokkan ayatayat dalam topik tertentu; (2) Mendeskripsikan pemikiran-pemikiran para mufassir atau intelektual tentang tema tertentu; (3) Mencari hadist-hadist

106 Ibid., 2.

107 Amina Wadud Muhsin, Qur'an Menurut Perempuan, 19.

138 | Muṣhaf: Jurnal Tafsir Berwawasan Keindonesiaan Volume 1. Nomor 1, Desember 2020. 
yang ada kaitannya dengan yang akan diteliti guna memperkuat tema yang dimaksud; (4) Membuat kesimpulan dengan analisis kritis.

Amina Wadud dalam menafsirkan surat al-Nisa' ayat 34 lebih menekankan pada susunan bahasa yang sering digunakan dalam menggambarkan superioritas laki laki. yakni lafal qawwamūn dan fadala. Seorang laki-laki bisa dikatakan qawwamun apabila memenuhi dua sayarat pertama, pelebihan" seperti apa yang diberikan. Kedua, mereka membiayai hidup perempuan dari harta mereka. Namun apabila kedua syarat tersebut tidak dapat terpenuhi maka, laki-laki tidak "qawwām" atas perempuan. Lafal fadala, menurut Amina mengindikasi adanya hubungan fungsional antara laki-laki dan perempuan, hal ini ditandai dengan adanya huruf jer bi (ba' sababiyah) serta penggenaan lafad ba'dun (sebagian ) setelah lafal fadala. ${ }^{108}$

Sedangkan Zaitunah lafal qawwämün dalam ayat tersebut mengandung makna sebagai pengayon penopang dan penaggung jawab. Karena menurutnya, kepemimpinan merupakan suatu sifat orang mukmin baik pria maupun wanita. Lebih lanjut ia mengatakan ayat tersebut bukan pernyatan normatif akan tetapi kontekstual dalam arti, makna dari kata qawwamun dapat berubah sesuai situasi dan kondisi yang menyertainya.

Selanjutnya adalah masalah nuг̧büz yang sering dijadikan alasan seorang laki-laki melakukan kekerasan terhada perempuan khusnya dalam keluraga. Amina wadud memaknai kata nuгbür sebagai gangguan keharmonisa dalam rumah tangga. Dalam menyelesaikan perkara nuzyuz alQur'an telah menetapkan solusi yaitu menasehati, pisah ranjang dan memukul. Dalam menaggapi solusi yang ditawarkan oleh al-Qur'an tersebut Amina lebih mengutamakan bermusyawarah tanpa ada percekcokan dengan harapan solusi yang ditawarkan tidak samapai pada tahap yang terakhir yaitu memukul.

Lain halnya dengan Zaitunah Subhan, ia mengatakan bahwa seorang perempuan dikatakan nu₹hbur apabila ada unsur kesengajaan terkait nuzyuznya tersebut serta tidak mempunyai alasan yang jelas. Kemudian dalam memaknai kata daraba, Zaitunah lebih memilih memutus hubungan secara total baik dalam hal nafkah lahir maupun batin dalam menyadarkan seseorang yang telah berlaku nuгbür.

\section{Kesimpulan}

Dari kajian tentang kebebasan perempuan diatas dalam perspektif Amina Wadud dan Zaitunah Subhan maka, penulis dapat menyimpulkan sebagai berikut: Amina Wadud dalam menafsirkan ayat al-Nisāa ayat 34 terkait

${ }^{108}$ Ibid., 126.

139 | Muṣhạa: Jurnal Tafsir Berwawasan Keindonesiaan Volume 1. Nomor 1, Desember 2020. 
kepemimpinan rumah tangga, menetapkan laki-laki sabagi pemimpin dengan dua syarat. (1) "pelebihan" seperti apa yang diberikan. (2) laki-laki membiayai hidup perempuan dari harta mereka. Sedangkan Zaitunah menafsirkan ayat al-Nisa' ayat 34 sebagai pengayom, penopang, penanggung jawab atau penjamin (dalam hal kewajiban memberi nafkah terhadap istrinya). Kemudian dalam hal nuz̧üz. menurut Amina Wadud dan Zaitunah sepakat bahwasanya kata nu₹hūz tidak hanya diperuntukan bagi istri akan tetapi juga untuk suami. Sedangkan dalam hal kebebasan perempuan dalam ranah publik, pendapat Amina dan Zaitunah dapat disimpulkan bahwasanya tidak ada halangan bagi seorang perempuan untuk berkarir diuar rumah dan berdedikasi kepada keluarga dan masyarakat dengan syarat wanita tersebut dapat menjaga kehormatannya.

Persamaan penafsiran anatara Amina dan Zaitunah dalam menafsirkan kebebasan adalah, (1) pandangan budaya patriarki terhadap kaum perempuan. Mereka berdua sepakat bahwasanya budaya patriarki bukanlah yang dikehendaki oleh al-Qur'an, karena tidak ada satu ayat-pun yang membenarkan budaya patriarki yang berkembang di masyarakat. (2) mereka berdua sama-sama ingin megungkapkan prinsip normatif teks alQur'an terkait keadilan gender. Hal ini karena realitas yang ada dalam masyarakat, khususnya tentang perempuan masih jauh dari apa yang maksud oleh al-Qur'an.

Adapun perbedaanya adalah; dalam penggunaan metode Amina Wadud menggunakan metode hermeneutika yang digagas oleh fazlur Rahaman. Sedangkan Zaitunah memilih menggunakan metode maudū' $\bar{\imath}$ dalam menafsirkan ayat al-Qur'an. Amina Wadud dalam menafsirkan surat al-Nisa' ayat 34 lebih menekankan pada susunan bahasa yang sering digunakan dalam menggambarkan superioritas laki laki. yakni lafadz qawwāmūn dan fadala. Sedangakan Zaitunah Subhan lafal qawwāmūn dalam ayat tersebut mengandung makna sebagai pengayon penopang dan penaggung jawab. Karena menurutnya, kepemimpinan merupakan suatu sifat orang mukmin baik pria maupun wanita. Dalam hal nuzyuz Amina wadud memaknai kata nuzhīz sebagai gangguan keharmonisa dalam rumah tangga. Sedangkan Zaitunah Subhan mengatakan bahwa seorang perempuan dikatakan nu₹bür. apabila ada unsur kesengajaan terkait nuzyuznya tersebut serta tidak mempunyai alasan yang jelas 
Penafsiran Zaitunah Subhan Dan Aminah Wadud Tentang Kebebasan Perempuan,

\section{Daftar Pustaka}

Akbar, Ali. 2020, Arkeologi Al-Qur'an: Penggalian Pengetahuan Keagamaan, Jakarta: Lembaga Kajian dan Peminatan Sejarah.

Amirullah, Abdul Karim. 1989, Tafsir al-Azhar, Jilid 4, Singapur: Pustaka Nasional PTE LTD.

Anthon, Farah. 1988, Ibnu Rusyd wa Falsafatubu, Beirut: Dar al-Farabi

Ashfahani (Al). 1961, al-Mufradat fi Garib al-Qur'an, Mesir: Mushtafa alHalabi.

Baidan, Nashruddin. 2002, Metode Penfsiran al-Qur'an, Yogyakarta: Pustaka Pelajar.

dkk, Rodiah. 2010, Studi al-Qur'an Metode dan Konsep Yogyakarta: eLSAQ Press.

Engineer, Asghar Ali. 2003, Matinya Perempuan: Transformasi al-Qur'an, Perempuan dan Masyarakat Modern, terj. Ahmad Affandi dan Muh. Ihsan, Yogyakarta: IRCiSoD

Fakih, Mansour. 1996, Analisis Gender dan Transformasi Sosial, Yogyakarta: Pustaka Pelajar.

Fatawati, Hanik. 2013, Penafsiran Amina Wadud Mubsin Tentang Bidadari Dalam Al-Qur'an: Kajian Hermeneutika, Skripsi: IAIN Walisongo Semarang.

http://dedikayunk.wordpress.com/2014/11/19/biografi-dan-pemikiranamina-wadud/

http:/ / fawwazmuhammad.tumbir.com/post/16/92312678032/atomistik

http://padamu.net/pendidikan-dan-perempuan, Jum'at, 7 februari 2020, jam 10:30)

https://www.acdemia.edu/17623622/Biografi dan Pemikiran Sosok Ami na Wadud

Imam al-Nasa’i, 1992, Sunan Nasa’i, terj. Bey Arifin dan Yunus Ali Mukhdo, Semarang: CV Asy Syifa.

Irsyadunnas, 2015, Tafsir Ayat-Ayat Gender Ala Amina Wadud Perspektif Hermeneutika Gadamer, Jurnal Musawa, Vol. 14, No. 2.

Jamal (al) Ibrahim Muhammad Hasan. 2014, Khadijah Teladan Agung Wanita Mukminah, Cet. 1, Trj. Khalid Abdullah dkk. Jawa Tengah:Insan Kamil.

Ju'fi (al) Muhammad bin Isma'il Abu 'Abdullah al-Bukhari. 1987, Shahih Bukhar: Jami'u al-Shahih al-Mukhtasyar, Bairut: Dar Ibnu Katsir.

Kamil, Muhammad. Penafsiran Wadribubunna dalam Surat al-Nisa' ayat 35, (Skripsi: UIN Sunan Ampel Surabaya)

Katsir, Ibnu. 2004, Tafsir al-Qur'an al-Azim, juz 19, terj. Bahrul Abu Bakar Bandung: Sinar Baru Algensindo. 
Penafsiran Zaitunah Subhan Dan Aminah Wadud Tentang Kebebasan Perempuan,

Kementrian Agama Republik Indonesia. 2010, Al-Qur'an dan Tafsirnya, Jakarta: Lentera Abadi.

Khurzman, Charles. 2001, Wacana Islam Liberal: Pemikiran Islam Kontemporer Tentang Isu-Isu Global, Jakarta: Paramadina.

Lestari, Lutfiani. 2018, Studi Tentang Kristen Ortodoks Yunani di Surabaya, Skripsi: UIN Sunan Ampel Surabaya.

M. Djunaidi Ghony dan Fauzan Almanshur. 2012, Metode penelitian Kualitatif, Yogyakarta: Al-Ruzz Media.

M. Echol, Jhon dan Shadily, Hassan. 1983, Kamus Inggris Indonesia, Jakarta: Gramedia. Cet. I

Magfiroh, Fika. 2016, Wawasan al-Qur'an terhadap Perempuan (Kajian Tafsir Maudlu'i), Skripsi: IAIN Tulungagung.

Maliki, Jalaluddin Muhammad bin 'Abdullah bin. tt, Syarab Ibnu 'Aqil 'ala Alfiah, Surabaya: Dar al-Ilmu.

Mansyuri, Arif. 2006, Skripsi, Konstruksi Tafsir Feminis: Studi pemikiran Amina Wadud atas Kesetaraan Gender dalam Al-Qur'an.

Maraghi (Al). Ahmad Mustafa. 1992, Terjemah Tafsir al-Maraghi, Jilid 14, Semarang: CV. Toha Putra Semarang.

Muhammad, Hussein. 2004, Islam Agama Ramah Perempuan, Yogyakarta: LKiS.

Muhammad, Su'aib H. 2013, Tafsir Tematik: Konsep, Alat Bantu, dan Contob Penerapannya, Malang: UIN MALIKI Press.

Muhsin, Amina Wadud. 1992, Wanita dalam Al-Qur'an, terj. Yaziar Radianti, Bandung: Pustaka.

Muliadi, Erlan. 2017, Telaah atas Pemikiran Amina Wadud Mubsin dalam 'Inside The Gender Jihad Women's refprm in Islam”, Jurnal: al-Qawwam. Vol. 11, No. 2

Munawwarah, Syarifatil. 2018, Siti Khadijad Ummul Mukminin: Biografi dan Peran dalam Mendampingi Rasulullah, Skripsi: UIN Alauddin Makassar.

Mutrofin, 2013, Kesetraan Gender dalam Pandangan Amina Wadud dan Riffat Hasan, Jurnal: Tasawwuf dan Pemikiran Islam. Vol.3, no. 1

Nadawi (al) Sayyid Sulaiman. 2007, 'Aisyah Potret Wanita Mulia Sepanjang Zaman, Jawa Tengah: Insan Kamil

Neufeldt, Victoria. Webster's New World Dictionary, (New York: Webster's New World Cleveland, 1984)

Qutb, Sayyid. 2000, Tafsir fi Zhilali Qur'an, juz 8, Terj. As'ad Yasin, dkk, (Jakarta: Gema Insani Press.

Quthb, Sayyid. 1980, Fi Zhilal al-Qur'an, Kairo: Dar al-Syuruq.

Rahman, Fazlur. 1985, Islam dan Modernitas: Tantangan Transformasi Intelektual, Bandung: Puataka.

142 | Muṣhạa: Jurnal Tafsir Berwawasan Keindonesiaan

Volume 1. Nomor 1, Desember 2020. 
Penafsiran Zaitunah Subhan Dan Aminah Wadud Tentang Kebebasan Perempuan,

Ridlo, Rasyid. 1973, Tafsir al-Manar, Mesir: Al-Haiah al-Misriyyah.

Rusyd, Ibnu. 1998, Talkhish al-Siyasah li Aflathon, Terj. Hasan Majid al-Ubaidi dan Fathimah Kazhim al-Dzahabi, Beirut: Dar al-Thali'ah.

Salim, Hadiyah. 1991, Wanita Islam: Kepribadian dan Perjuangannya, Bandung:

Shihab, Quraish. 1996, Wawasan al-Qur'an: Tafsir Maudbu'i atas Pelbagai Persoalan Umat, Jakarta: Mizan.

Shihab, Quraish. 1996, Wawasan Al-Qur'an: Tafsir Mudbu'i atas Pelbagai Persoalan Umat, Bandung: Mizan.

Sonhaji. 2017, Keharmonisan Keluarga Nabi Mubammad Dengan Istrinya 'Aisyah dalam kitab Shahih Bukhari, Skripsi: UIN Syarif Hidayatullah Jakarta.

Subhan Zaitunah. 2015, Al-Qur'an dan Perempuan: Menuju Kesetaraan Gender dalam Penafsiran, Jakarta: Prenada Media Group.

Subhan, Zaituna. 1999, Tafsir Kebencian: Studi Bias Gender dalam Tafsir alQur'an, Yogyakarta: LKiS.

Subhan, Zaitunah. 2004, Membina Keluarga Sakinah, Yogyakarta: LKis.

Subhan, Zaitunah. 2018, Al-Qur'an dan Perempua: Menuju Kesetaraan Gender dalam Penafsiran, Jakarta: Prenada Media Group.

Suharso dan Nigsih, Ana Retno. 2002, Kamus Besar Bahasa Indonesia, Jakarta: Balai Pustaka.

Susanti. 2014, Jurnal Teosofi, Volume 4, no.1 Juni

Suyuthi, (Al). 2008, Lubab al-Nuqul fi Asbab al-Nuzul, Kairo: Dar alMuttaqim.

Syahrur, Muhammad. 2004, Metodologi Fikih Islam Kontemporer, Terj. Syahiron Syamsuddin dan Burhanuddin, Yogyakarta: eLSAQ Press.

Syamsuddin, Syahiron. 2008, Hermeneutika Al-Qur'an dan Hadist, Yogyakarta: Elsaq.

Tanwir. 2017, Kajian Eksistensi Gender Dalam Perspektif Islam, Jurnal alMaiyyah: STAIN Pare-Pare. Vol. 10

Thabari (al) Abu Ja'far Muhammad bin Jarir bin Yazid. 1412 H, Tafsir alThabari, Jilid IV, Beirut: Darul Kitab.

Umar, Nasaruddin. 2001, Argumen Kesetaraan Gender Perspektif al-Qur'an, Jakarat: Paramadina.

Umar, Nasaruddin. 2001, Argumen Kesetaraan Gender Perspektif Al-Qur'an, Jakarta: Paramadina.

Wahidi (al) Ahmad. 1969, Asbabun Nuzul al-Qur'an, Kairo: Dar al-Kitab alJadid.

Ya'qub, Ali Mustafa. 2003, Hadist-Hadist Bermasalah, Jakarta: Pustaka Firdaus. Yusron, M. 2006, Studi Kitab Tafsir Kontemporer, Yoyakarta:TH-Press.

Zakariya, Abu Husayn Ahmad bin Faris bin. 1994, Mu'jam al Maqayis fi alLughah, Beirut: Dar al-Fikr.

143 | Muṣhaf: Jurnal Tafsir Berwawasan Keindonesiaan

Volume 1. Nomor 1, Desember 2020. 
Diana Khotibi

Penafsiran Zaitunah Subhan Dan Aminah Wadud Tentang Kebebasan Perempuan,

Zenrif, Fauzan. 2011, Tafsir Fenomenologi Kritis: Interrelasi Fungsional antara Teks dan Realitas, Malang: UIN-Maliki Press.

144 | Muṣhạaf: Jurnal Tafsir Berwawasan Keindonesiaan Volume 1. Nomor 1, Desember 2020. 